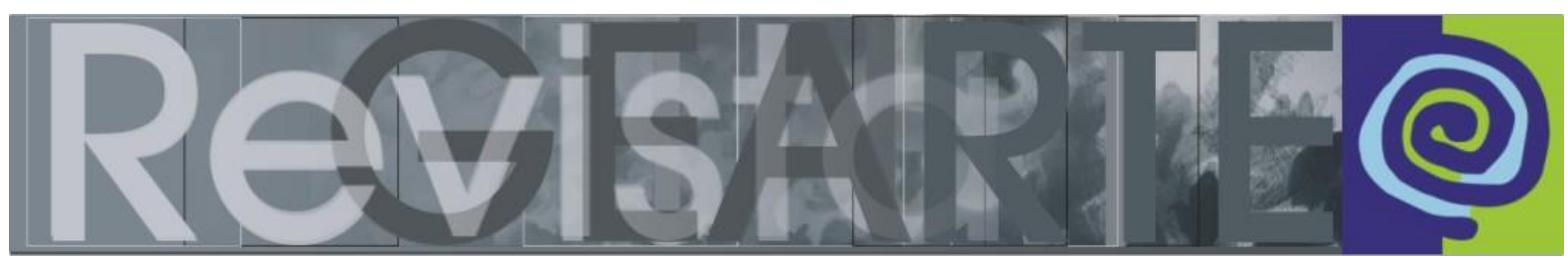

ISSN 2357-9854 | e-ISSN 2596-3198 (online)

\title{
A pálida História das Artes Visuais no Brasil: onde estamos negras e negros?
}

\author{
Renata Aparecida Felinto dos Santos \\ (Universidade Regional do Cariri — URCA, Juazeiro do Norte, Ceará)
}

\begin{abstract}
RESUMO - A pálida História das Artes Visuais no Brasil: onde estamos negras e negros? Este artigo trata de como as produções em artes visuais que foram e são realizadas por artistas visuais negras e negros têm sido apagadas dos registros históricos, como livros e, consequentemente, do ensino de artes visuais. Quando são apresentados esses protagonismos e produções o são por meio de capítulos específicos em publicações e momentos pontuais em sala de aula para tratar de "arte negra" ou "afro-brasileira", dando a frágil percepção de que estamos incluindo a Lei 10.639/03 no currículo escolar, quando em verdade, continuamos a apartar os saberes da visualidade criados por essas e esses artistas daquele que chamamos de Artes Visuais, com letras maiúsculas. Propormos que artistas visuais negras e negros tenham suas biografias e criações aproximadas dos movimentos artísticos que já são estudados em artes visuais, quando possível, e quando não o for, que sejam apresentadas e apresentados como produção coetânea e paralela ao reconhecimento acadêmico e hegemônico, contextualizando sempre as disputas e supressões de narrativas que colocam o eurocentrismo como eixo da história das artes visuais e da humanidade. Dessa forma, propomos que a decolonialidade seja praticada em sala de aula e não apenas um termo contemporâneo utilizado nos estudos acadêmicos em humanidades numa perspectiva antirracista dos escritos.
\end{abstract}

PALAVRAS-CHAVE

Artes visuais. Artistas visuais negros e negras. Lei 10.639/03. História e ensino de artes visuais.

RESUMEN - La pálida Historia de las Artes Visuales en Brasil: ¿dónde estamos negras y negros? - Este artículo trata de cómo las producciones en artes visuales que fueron y son realizadas por artistas visuales negras y negros han sido borradas de los registros históricos como libros y, consecuentemente, de la enseñanza de artes visuales. Cuando se presentan esos protagonismos y producciones, lo son por medio de capítulos específicos en publicaciones y momentos puntuales en el aula para tratar de "arte negro" o "afro brasileña", dando la frágil percepción de que estamos incluyendo la ley 10.639/03 en el currículo cuando en verdad, seguimos apartando los saberes de la visualidad creados por esas y esos artistas de aquel que llamamos Artes Visuales, con letras mayúsculas. Proponemos que artistas visuales negros y negras tengan sus biografías y creaciones aproximadas de los movimientos artísticos que ya se estudian en artes visuales, cuando sea posible, y cuando no lo sean presentadas y presentadas como producción coetánea y paralela al reconocimiento académico y hegemónico, contextualizando siempre las disputas y supresiones de narrativas que sitúan al eurocentrismo como eje de la historia de las artes visuales y de la humanidad. De esta forma, proponemos que la decolonialidad sea practicada en el aula y no sólo un término contemporáneo utilizado en los estudios académicos en humanidades en una perspectiva antirracista de los escritos.

PALABRAS CLAVE

Artes Visuales. Artistas visuales negros y negras. Ley 10.639/03. Historia y enseñanza de artes visuales.

O ensaio que desenvolverei nas páginas a seguir não se molda nas fórmulas convencionalmente prescritas para trabalhos acadêmicos e/ou contribuições científicas. Nem está o autor deste interessado no exercício de qualquer tipo de ginástica teórica, imparcial e descomprometida. Não posso e não me interessa transcender a mim mesmo (...) considero-me parte da matéria investigada. Somente da minha própria experiência e situação no grupo 


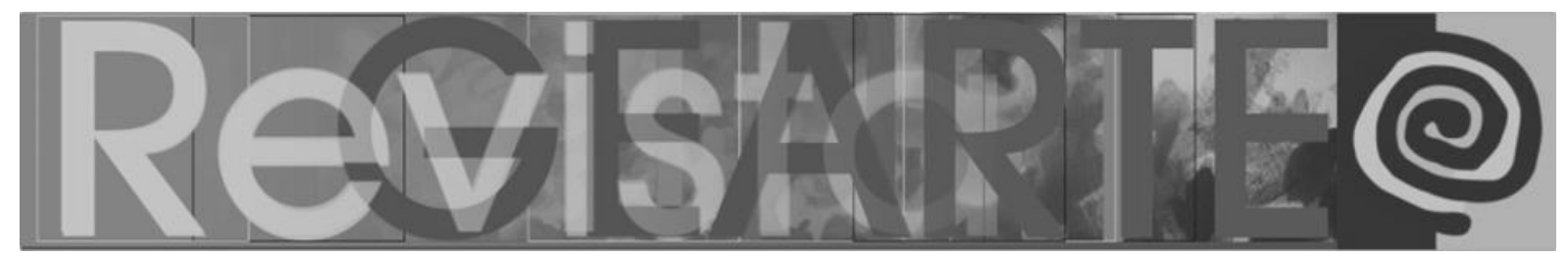

étnico-cultural a que pertenço, interagindo no contexto global da sociedade brasileira, é que posso surpreender a realidade que condiciona o meu ser e o define (Abdias Nascimento) 1.

A nossa sociedade brasileira tem se mostrado absolutamente controversa no que diz respeito à teoria e à prática da democratização dos acessos, dos meios de representatividade, visibilidade e diversidade de grupos humanos que a compõem.

Estando nós inseridas e inseridos numa sociedade plurirracial é urgente que, de fato, os conteúdos que compõem os currículos escolares da Educação Infantil à Superior contemplem as participações e contribuições de todos os povos que historicamente constituem o povo brasileiro, dos quais enfatizamos os grupos autóctones, povos da terra e/ou das florestas que vimos impingindo o nome indígenas desde 1500, conforme a nomeação conferida pelos portugueses; lembramos dos já representados povos europeus e seus descendentes que, desde então, num projeto de dominação mercantil e capitalista da economia, também impôs sua história e modos de organização da sociedade para outras populações; e neste escopo também aqui destacamos os povos trazidos forçadamente do continente africano para trabalhar compulsoriamente como mão-de-obra escravizada. A nossa plurirracialidade tem como base esse tripé tão festejado de "três raças" e, lamentamos que essa formação seja abordada e disseminada em contextos educacionais de forma a romantizar e amenizar a brutalidade dos acontecimentos que desembocam na convergência dos grupos humanos mencionados, bem como de suas histórias e culturas.

Abdias Nascimento (1914-2011) foi um dos primeiros ativistas do movimento negro a pontuar assertivamente sobre as formas de eliminação do povo negrodescendente, afrodescendente, afrobrasileiro, como queiram, a partir de sua obra O genocídio do negro brasileiro, publicada em 1978 e reeditada em 2016. Nesta obra que reúne uma coletânea de ensaios, ele aponta que a eliminação do corpo físico do homem negro é a culminância de um extenso e agressivo processo de invisibilização, omissão, subordinação e humilhação dessa parcela da população. Um dos pontos que Nascimento aprofunda é a urgência de revermos o currículo escolar e a ausência de disciplinas que contemplem as populações africanas e afro-brasileira e suas inestimáveis contribuições para a construção e sedimentação da história e cultura brasileira. Ao mesmo tempo em que se coloca como intelectual que, uma vez excluído sistematicamente dos espaços de produção de saber no Brasil, não necessariamente precisa seguir normas ditadas por esses mesmos lugares para expor suas ideias. Compartilhamos desse entendimento sobre a produção de conhecimento a partir de uma existência negra num contexto de opressão e de genocídio. Abdias Nascimento, presente! 


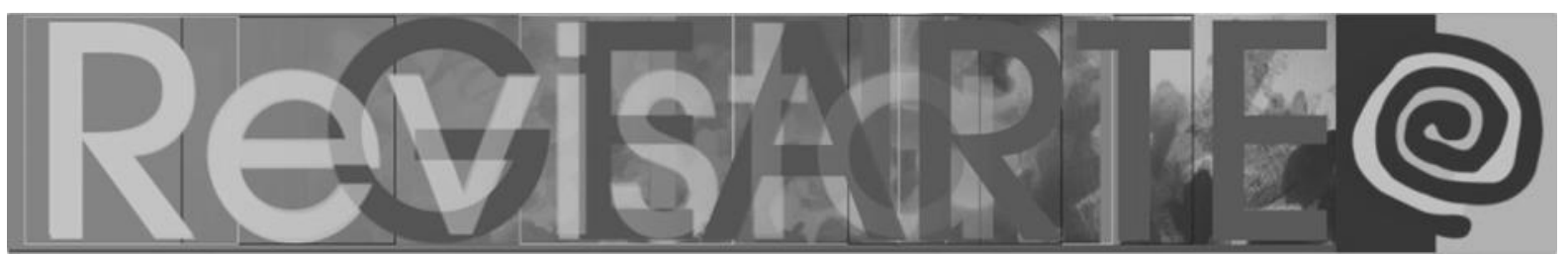

Considerando o preâmbulo acima exposto, para a construção deste artigo, focaremos na invisibilidade destes últimos povos, os africanos e descendentes no contexto brasileiro e como nesse processo histórico a violência da escravização se transmuta em violência da subcidadania que, por sua vez, se converte em subrepresentação.

No que tange ao sistema da arte essa palidez, essa ausência dos assuntos que dizem respeito às negras e negros é evidente, desde o acesso à educação em artes visuais, seja do ponto de vista da formação humana quanto do da formação profissional; do acesso aos meios de criações artísticas; das formas de exibição, comercialização, escritas e registros dessas criações e acontecimentos; bem como os instrumentos de análises e de abordagens que, por vezes, desconsideram e negligenciam os contextos históricos e sociais de inserção da pessoa negra no Brasil.

É desumano e desonesto qualquer abordagem acerca da história das pessoas negradescendentes no Brasil que sejam acríticas do ponto de vista do escopo sóciohistórica. A subcidadania também é uma forma de sub-humanidade a qual está condicionada a população negra brasileira. Realizar escritas que apontem para essa realidade e a reflexão acerca dela é uma forma de reparação e de concretização da utopia de equiparação, ao tempo em que as mesmas enfraquecem o mito da democracia racial que se forja nos anos de $1930^{2}$ e que persistindo até a atualidade.

Discorreremos ao longo do texto sobre essas inteligências, inventividades e estéticas, que são nada ou pouco representadas como histórias que discutem a nossa sociedade a partir da criação artística provinda do segmento negrodescendente.

2 "A democracia racial é um termo usado por algumas pessoas para descrever relações raciais no Brasil. O termo denota a crença de alguns estudiosos que o Brasil escapou do racismo e da discriminação racial. Estudiosos afirmam que os brasileiros não vêem uns aos outros através da lente da raça e não abrigam o preconceito racial em relação um ao outro. Por isso, enquanto a mobilidade social dos brasileiros pode ser limitada por vários fatores, gênero e classe incluído, a discriminação racial é considerada irrelevante (dentro dos limites do conceito da democracia racial). O conceito foi apresentado inicialmente pelo sociólogo Gilberto Freyre, na sua obra Casa-Grande \& Senzala, publicado em 1933. Embora Freyre jamais tenha usado este termo nesse seu trabalho, ele passou a adotá-lo em publicações posteriores, e suas teorias abriram o caminho para outros estudiosos popularizarem a ideia". PORTO, Gabriella. Democracia Racial. Infoescola. Disponível em: https://www.infoescola.com/sociologia/democracia-racial/. Acesso em: 04 mar. 2019. 


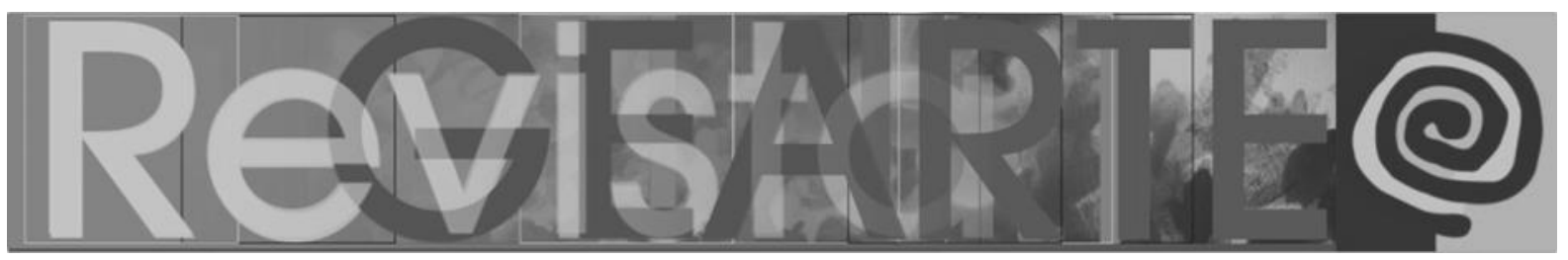

Nesse entremeio, apontamos como a seletividade de quem, do que e de como se escreve a história das artes visuais no Brasil, de como se inscrevem essas biografias e produções e, consequentemente, como não outorgam espaço e cor às/aos artistas visuais negrodescenentes.

Se insistiremos em entender o Brasil como uma sociedade plurirracial e democrática, essa sociedade precisa assentir igualdade econômica, social e cultural a todas e todos, o que por um lado sabemos também ser uma quimera na medida em que as conquistas das chamadas minorias políticas e sociais são paulatina e violentamente eliminadas pelos grupos das elites que estão secularmente nos lugares de poder. Como exemplo, poderíamos mencionar a deposição de Dilma Rousseff ${ }^{3}$ do cargo de presidenta da nação no ano de 2016, que foi equivocadamente fundamentada em erros administrativos muito semelhantes aos cometidos por homens que já estiveram ocupando este mesmo posto. Notemos como as respostas negativas a esses equívocos foram desproporcionalmente combatidas. E na atualidade é sabido que não houve crime de improbidade administrativa ou qualquer outro erro dessa natureza imputado a ela, vivenciamos e até colaboramos para o avolumamento de factoides que culminaram num golpe que objetivava frear avanços proporcionados por políticas sociais que conferiam alguma equidade a grupos historicamente prejudicados como mulheres, pobres e não-brancos. Isto posto, para exemplificarmos que a utopia da igualdade é quase impossível se sequer o início de concretização de politicas mínimas de equidade advindas da escolha popular são respeitadas por setores ditos dominantes e, consequentemente, historicamente privilegiados.

Dessa forma, observamos já há algum tempo que o discurso generalizado e primário de nossa propalada miscigenação como valor positivo tem apaziguado exigências de cumprimentos de reivindicações e demandas que se alinham à agenda dos movimentos negros Brasil afora. Nessa montante estão as conquistas como a Lei

3 Perícia conclui que Dilma não participou de pedaladas fiscais. O Globo. 27 jun. 2016. Disponível em http://g1.globo.com/jornal-nacional/noticia/2016/06/pericia-conclui-que-dilma-nao-participou-depedaladas-fiscais.html. Acesso em: 03 mar. 2019. 


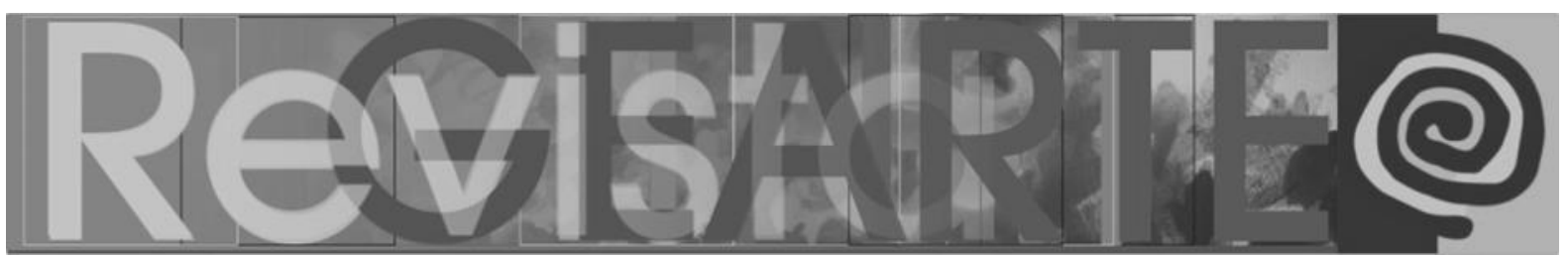

10.639/03 que se converte em 11.645/08 e que, grosso modo, obriga o ensino de histórias e culturas dos povos africanos, afro-brasileiro e indígenas nas escolas, que deveria abarcar também todos os cursos das áreas de exatas, humanas e artes que se voltem às licenciaturas e formação de docentes.

Conforme nos aponta o Jerry D’Ávila, o currículo praticado pelas escolas do Brasil da Era Vargas focava justamente no apagamento de diferenças étnico-raciais e na uniformização tanto da população brasileira quanto de suas diferenças históricas e culturas. O que culminou na invisibilização de narrativas que retiravam a centralidade do protagonismo branco e europeu tendo como fundamento as pseudo-ciências raciais do fim do século 19 e início do século 20 como o darwinismo social, o evolucionismo social e a frenologia:

(...) uma elite branca médica, científico-social e intelectual emergente transformou suas suposições sobre raça em politicas educacionais. Essas politicas não apenas refletiam as visões da elite sobre degeneração; elas projetavam essas visões em formas que geralmente contribuíam para a desvantagem de brasileiros pobres e não-brancos, negando-lhes o acesso equitativo aos programas, às instituições e às recompensas sociais que as politicas educacionais proporcionavam (...) Essas políticas não só colocavam novos obstáculos no caminho da integração social e racial no Brasil como deixavam apenas pálidos sinais de seus efeitos, limitando a capacidade dos afro-brasileiros de desafiarem sua injustiça inerente. ${ }^{4}$

Ao impedimento de que pobres e não-brancos tivessem acesso a um conjunto de medidas de reparação histórica e social que, por vezes, eram convertidas em políticas de Estado, denominamos epistemicídio, segundo a filósofa Sueli Carneiro 5 . Isto significa que é urgente que nos esforcemos no processo de revisão desses conhecimentos existentes nos currículos escolares, bem como produzamos novos conhecimentos, exploremos e revelemos saberes soterrados pela terra infértil do racismo, do machismo e dos meios de colonialidade, esta última sendo uma nódua do colonialismo histórico que contamina ainda hoje as produções de registros, narrativas,

4 DÁVILA, Jerry. Diploma de brancura: política social e racial no Brasil - 1917-1945. São Paulo: Editora UNESP, 2006. p. 21-2.

5 CARNEIRO, Sueli. Epistemicídio. Geledés. 04 set. 2014. Disponível em https://www.geledes.org.br/epistemicidio/. Acesso em: 03 mar. 2019. 


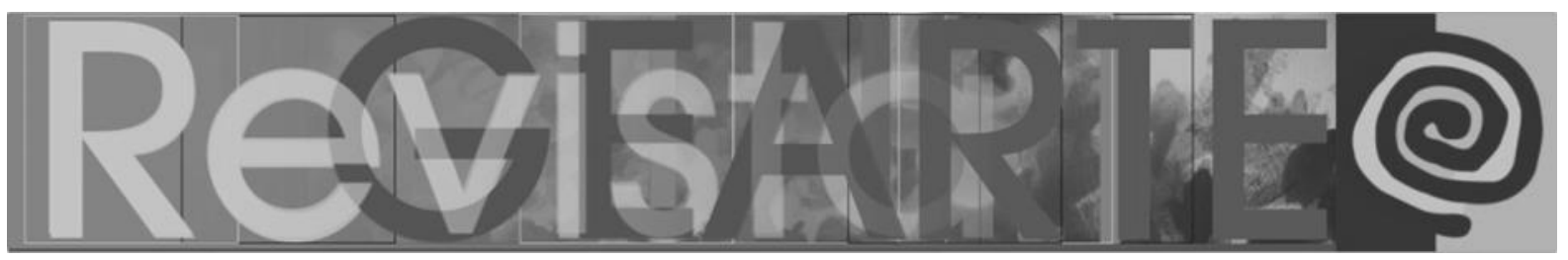

conhecimentos e os modos e meios de educação que se afastem do que chamamos de norma culta, mas que também é nada mais, nada menos que o modus operandi branco europeu.

Se caminharmos para essa direção, a da novas possibilidades de leituras do que produzimos historicamente no Brasil em se tratando de Artes Visuais, também é premente a pesquisa que se dedique a revisitar as Artes Visuais produzidas nos períodos colonial, imperial e republicano e a forma como essa história está escrita, quais as personalidades contempladas, quais são e como se constituíram os movimentos artísticos destacados, e como se dão os encadeamentos para a correlação de todos esses pontos. E nesse sentido, primeiramente precisamos alargam exponencialmente o parco espaço dedicado a nomeação dos povos africanos traficados para o Brasil, as suas localidades, os seus saberes, as suas tecnologias imprescindíveis para todos os modos de produção da colônia, do império e da república. Por isso, estamos questionando, numa sociedade plurirracial onde estavam e estão pessoas não-brancas que atuaram no que chamamos de sistema da arte e que, como desdobramento e extensão, também diz respeito às pessoas que educam a partir das Artes Visuais independentemente de sua origem étnico-racial.

O exercício de reflexão sobre esse pensar, fazer, escrever para além dos limites do que está impresso num livro, à venda numa galeria, exposto num museu é também o de identificar as falhas de uma sociedade na qual são poucas as pessoas que detinham e detém o poder de protagonizar a história, pessoas que compunham e compõem segmentos que sequer eram coadjuvantes e sim figuração. Grada Kilomba (1968-), artista e escritora afro-portuguesa, trata sobre a questão da descolonização do conhecimento produzido dentro da Academia, escrito na perspectiva única do homem branco como ser universal, e aponta para a urgência de se inscreverem conhecimentos pensados por pessoas provenientes de outros corpos diversos do desse homem, portanto, de outras realidades, com foco nas pessoas negras, nas mulheres negras: 


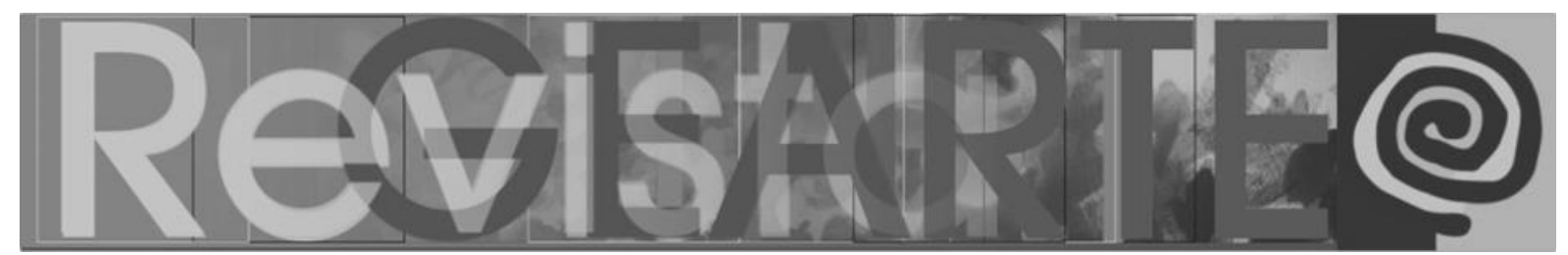

O conceito de conhecimento não se resume a um simples estudo apolítico da verdade, mas é sim a reprodução de relações de poder raciais e de genero, que definem não somente o que conta como verdadeiro, bem como em quem acreditar. Algo passível de se tornar conhecimento torna-se então toda epistemologia que reflete os interesses políticos específicos de uma sociedade branca colonial e patriarcal. (...)

A academia não é um lugar neutro, tampouco simplesmente um espaco de conhecimento e de sabedoria, da ciencia e erudicão, mas também é um espaco de v-i-o-l-e-n-c-i-a. Ela tem uma relacão muito problemática com Negritude. Aqui, temos sido objetificados/as, classificados/as, teorizados/as, desumanizados/as, infantilizados/as, criminalizados/as, brutalizados/as, sexualizados/as, exposto/as, exibidos/as e, por vezes, mortos/as. ${ }^{6}$

Para nossa sociedade é algo relativamente recente, novo, compreender as ausências de determinados grupos étnico-raciais ou sociais como violência, porém cada vez mais, intelectuais negras, especialmente as que se alinham ao feminismo interseccional ou intersecional ${ }^{7}$, tem denunciado que a omissão, o apagamento, a invisibilidade, a sub-representação são facetas da mesma violência que fere e elimina fisicamente indivíduos que compõem esses segmentos.

Muitos e muitas profissionais da educação perguntam-se como a Lei 10.6390/03, que foi modificada para 11.645/08, pode ser aplicada em sala de aula considerando do Ensino Infantil ao Ensino Superior e sendo realmente transformadora e profunda. No âmbito das artes visuais pensamos que a única forma de se ensinar história da arte com o foco na inserção e valorização de artistas visuais negras e negros é respeitando o tempo cronológico.

O que significa que elaborar livros de história da arte para qualquer segmento ou ciclo, criando-se capítulos exclusivos para a apresentação de artistas visuais

6 KILOMBA, Grada. Descolonizando o conhecimento. Instituto Goethe. Tradução Jéssica Oliveira. Disponível em http://www.goethe.de/mmo/priv/15259710-STANDARD.pdf. Acesso em: 03 mar. 2019.

7 "Interseccionalidade é um termo cunhado pela professora norte-americana Kimberlé Crenshaw em 1989. O conceito já existia, mas ela deu um nome a ele. A definição segundo seu livro é: 'A visão de que as mulheres experimentam a opressão em configurações variadas e em diferentes graus de intensidade. Padrões culturais de opressão não só estão interligados, mas também estão unidos e influenciados pelos sistemas intersecionais da sociedade. Exemplos disso incluem: raça, gênero, classe, capacidades físicas/mentais e etnia'." CARDOSO, Bia. Feminismo intersecional. Que diabos é isso? (e porque você deveria se preocupar). Blogueiras Feministas. 24 jul. 2014. Disponível em https://blogueirasfeministas.com/2014/07/24/feminismo-intersecional-que-diabos-e-isso-e-porquevoce-deveria-se-preocupar/. Acesso em: 03 mar. 2019. 


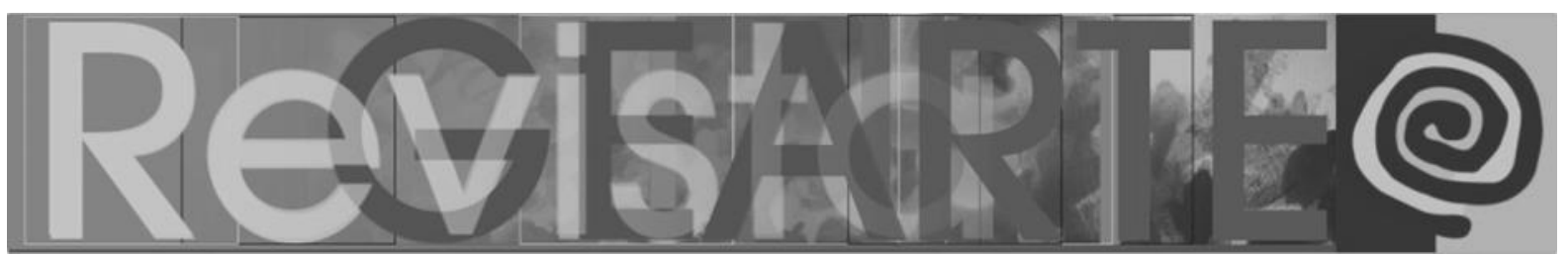

negras e negros é incorrer no que a própria branquitude aponta como segregação: "ah, mais uma exposição somente com artistas visuais de cor negra? Isso é racismo"; "Mas um livro inteiro somente com pintores negros do século XIX? Isso é segregação"; "Um curso de artes visuais que trata apenas de mulheres negras? E as brancas?". Bem, esses questionamentos, que para pessoas elucidadas acerca das temáticas urgentes no que se refere ao escopo do que tratamos neste artigo, são considerados descabidos e frutos de uma resistência agnosia em aprender sobre o que não se aprendeu; reconhecer o que não se conheceu; reparar o que não foi reparado. Sem eufemismos, o racismo se faz presente na área da educação quando profissionais que se entendem como bem informados e humanizados diante da urgência em termos uma educação para a equidade, não incorporam à revisão de artistas e temas apresentados e estudados em artes visuais.

Quando atentamos ao fato de que o ensino de história das artes visuais que contemple artistas e produções de não-brancas precisa estar alinhado à cronologia, não nos referimos aos estudos que seguem a linha do tempo ocidental. Ou seja, que para se estudar barroco, devemos antes passar pelo renascimento, ou que somente pode-se compreender o neoconcretismo se passarmos pelo modernismo. Não se trata da linearidade da linha do tempo. Até porque, há a necessidade de rompermos com essa dureza dessa linha a fim de possibilitarmos que esse ensino-aprendizagem rompa com os limites do modenismo, uma vez que em sala de aula, raramente se chega na produção de arte contemporânea.

Queremos dizer que em 2019, ainda estamos ensinando sobre artistas visuais do modernismo paulista sem expandir esse movimento de atualização estética, temática e pictórica para outros lugares do Brasil, e ainda, finalizamos o semestre no estudo de Abaporu, 1928, de Tarsila do Amaral (1986-1973); não ultrapassamos a Tarsila do Amaral! Estamos num intervalo de 100 anos entre o que se ensina nas escolas e o que se expõe nas bienais e nas galerias de artes visuais Brasil afora. Isso é grave, pois denuncia o distanciamento entre os conteúdos do currículo escolar que praticamos, o que teorizamos e a realidade, a contemporaneidade. 


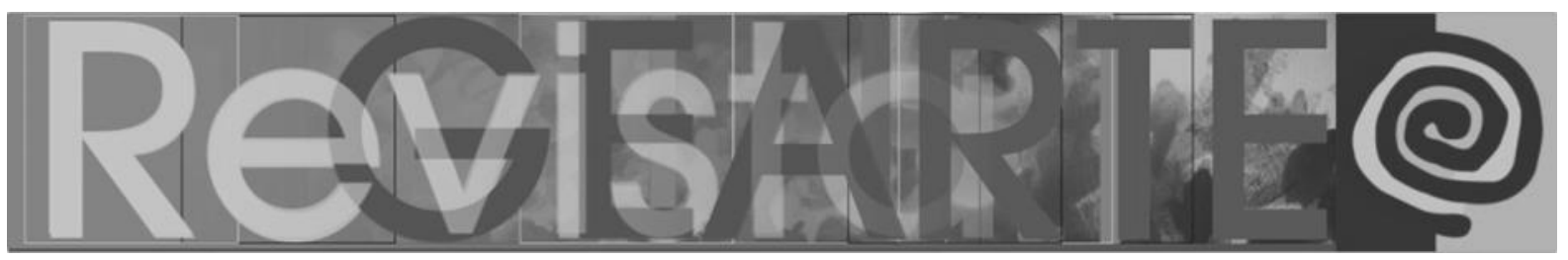

A cronologia consiste em apresentar artistas visuais negras e negros inseridos ou que produziram e produzem paralelamente às escolas e estilos apresentados em sala de aula, demonstrando dessa maneira que apesar de essas pessoas não serem reconhecidas no mesmo período histórico que artistas visuais de maior visibilidade, que suas produções estavam e estão alinhadas à escola ou estilo apresentado e estudado. Ou ainda, que mesmo que não estivessem ou estejam alinhadas, que sim, artistas visuais negras e negros existiam e existem e produziam e produzem obras diversas, mesmo à margem do sistema de arte porque historicamente também à margem da sociedade e dos acessos básicos como o de educação formal, de moradia, de saúde etc.

Dessa forma, a introdução do estudo dessas produções também contempla a contextualização e o alcance da dimensão de apartamento do povo negro em relação a uma gama de direitos, e que mesmo ser artista, que remonta um pensar e fazer inerentes à condição humana, torna-se um enorme desafio visto que além dessas condições básicas de existência, há um sistema que legitima (ou não) quais obras são relevantes, quais obras podem ou devem ser expostas como comercializáveis, quais biografias agregam valor às obras, etc. Nesse "etc." incluímos o poder de exibição dessas obras e as escritas que serão produzidas a partir delas. Quais artistas e consequentemente quais obras permanecem para a posteridade e representam parte de um conjunto de valores de um período histórico.

Propomos, assim, que pensemos na arte que se ensina nas escolas, a dos movimentos artísticos e seus estilos, das biografias de artistas visuais e de seus contextos de formação, a partir da inserção do indivíduo negrodescendente como profissional das artes visuais existente num determinado período histórico e cronológico. O que significa que bibliografias que tem sido produzidas sobre arte e educação, história da arte, ensino da arte e quaisquer outros temas e recortes afins que, porventura, tenham elaborado um capítulo especial somente para artistas visuais "negras", que essa bibliografia falhou porque ela replica o apartamento, o distanciamento, a marginalização. 


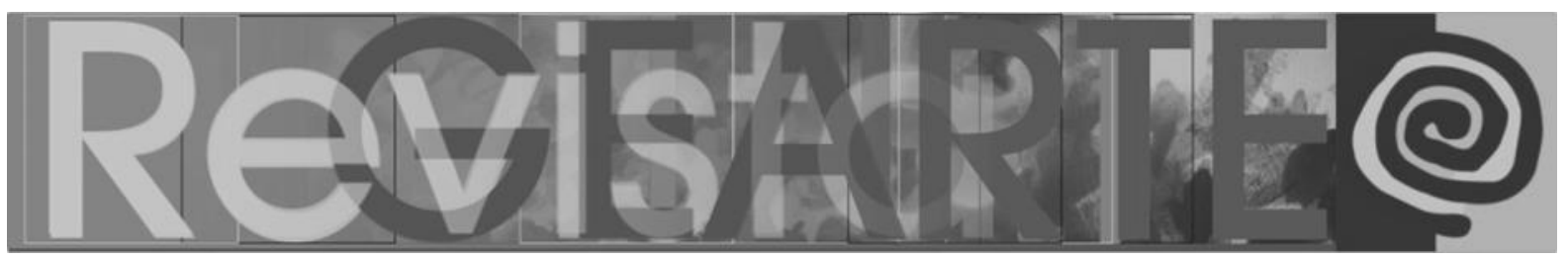

Falhamos ao não incorporar esses conhecimentos e produções desde sempre no que consideramos relevante e fundamental para ser assunto abordado em sala de aula a partir do currículo como saber humano. Falhamos porque permitimos que se propagasse a falsa noção de que um povo e uma cultura brasileiras uniforme sem atentarmos à amplitude territorial e, logicamente das gentes que a povoam. Falhamos ao considerar que tais saberes poderiam ser tema de aula somente em abril, como "comemoração" do Dia do Índio, ou como "celebração" do dia da assinatura da Lei Áurea, anteriormente, e agora em Novembro como forma de "festejar" o Dia da Consciência Negra. ${ }^{8}$ Falhamos ao considerar que esse momento em separado era suficiente. Falhamos ao deduzir que as crianças não-brancas não percebiam ou percebem as ausências de suas culturas originárias e familiares como temas valorizados pelos espaços de ensino e de aprendizagem. Falhamos ao reiterar os lugares desses estudos não-brancos e de suas propagações como secundários ou subordinados, assim como, historicamente esses povos tem sido tratados.

Propomos esse estudo da seguinte forma: se vamos estudar barroco, realismo, romantismo, neoclassicismo, impressionismo, modernismo, e assim por diante, até que cheguemos à produção de arte contemporânea, por movimento artístico que seja, devemos extrapolar os limites dos materiais bibliográficos, didáticos e paradigmáticos que temos à disposição, que estão aceitos pelo mercado editorial e parcialmente alinhados às subjetividades de interpretações da Lei de Diretrizes e Bases e dos Parâmetros Curriculares Nacionais em consonância com os textos das Leis 10.639/03, que se estende à Lei 11.645/08.

Nas disciplinas que constam nos PCN's, a saber Artes Visuais, Teatro, Dança e Música, obrigatórias por meio da LDB 9394/96, constam habilidades e domínios, experiências e vivências que estudantese devem acessar. Nelas não estão expressos movimentos artísticos, artistas e contextos fundamentais, nós quem os determinamos a partir dos currículos de cada escola privada ou pública, nós quem elencamos e

8 Dia o Índio, 19 de abril. Data da Abolição da Escravidão no Brasil, 13 de maio de 1888. Dia da Consciência Negra, 20 de novembro. 


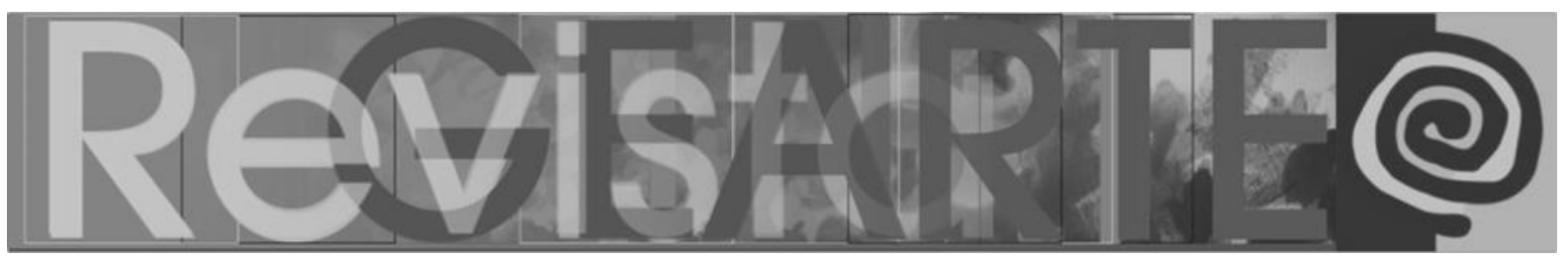

damos continuidade à história das artes visuais, nos que a tornamos menos pálidas e Ihe conferimos o colorido que tanto propagamos que caracteriza nossa cultura e nossa gente. E como o faremos? O que ou quem deixaremos de contemplar para abrir espaço a nomes importantes, porém menos conhecemos devido ao próprio processo de apagamento das diversidades Brasil afora que toma o país a partir do início do século 20? Com a proposição dessa nova prática não estamos excluindo nomes e movimentos que conquistaram seus lugares, mas sim considerando um revezamento, uma diversidade, uma ampliação que dê possibilidade de abrangermos mais, outras e outros.

Traremos aqui algumas proposições considerando a vasta história das artes visuais do Brasil, para percebemos um certo desenvolvimento das formas, dos materiais, das técnicas e de seus contextos tratando dessa historiografia à maneira dos hiperlinks, aos quais essa geração já se habituou.

Essas proposições de abordagem decolonial e não linear inicia-se pelo o que é considerado o primeiro movimento artístico brasileiro dentro dos paradigmas da arte ocidental: o barroco. Importado da Europa via Portugal, temos uma produção artística compreendida cronologicamente entre os séculos 18 e 19, cujas realizações seriam impossíveis sem a da mão de obra escravizada de origem africana.

O trabalho manual era considerado uma atividade menor, marginalizada, por isso, a compreensão da arte produzida naquele momento era bem diversa da que temos hoje, tanto artistas quanto a arte logravam de um status menos valorizado. Desempenhavam papéis de artífices e artesãos, fundamentais à produção inserida nesta escola artística, homens negros naquele contexto identificados como "pretos e pardos" ou ainda "homens de cor e mulatos" terminologias comumente encontradas na bibliografia que se refere aos autores dessas produções.

Estes atuavam em corporações de oficio sob a supervisão de um mestre, geralmente de origem portuguesa. Esses artífices e artesões deveriam, portanto, seguir cânones estéticos e temáticos de acordo com as ordens do mestre, na medida 


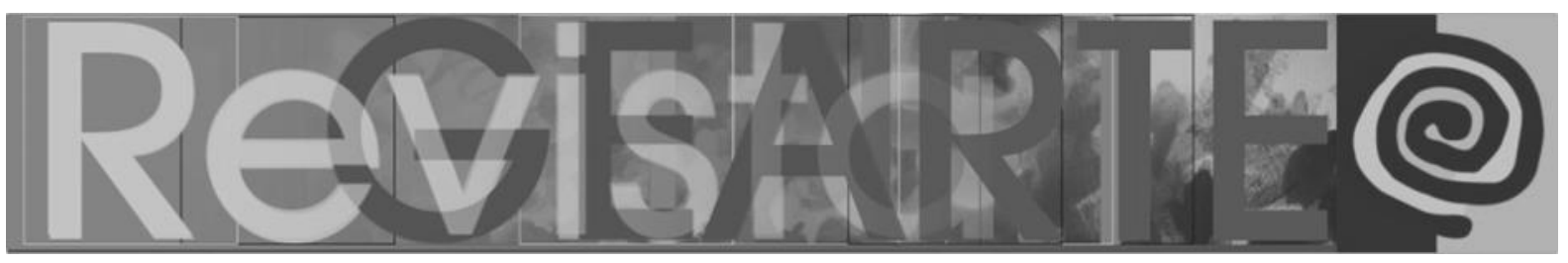

em que seus talentos e habilidades contribuíam para realizações de esculturas, objetos, construções arquitetônicas, em geral de cunho católico. Todavia, existiram também aqueles que, como homens livres, além de desenvolverem uma produção artística a partir de um estilo e estética próprias, também tinham outros artífices trabalhando para si, o que os alçava ao status de artistas autônomos. Os mineiros Valentim da Fonseca e Silva (1745-1813) e Antônio Francisco Lisboa (1730-1814), são dois desses casos isolados e focaremos brevemente neste último para exemplificar essa afirmação. Filho de uma escravizada de origem angolana e de um arquiteto português que Ihe concedeu a sua liberdade na pia batismal. Suas obras são reconhecidas como as de maior importância e projeção nas Américas durante o período colonial, ainda que sua abrangência material se restrinja à região do atual estado de Minas Gerais.

Podemos ainda mencionar artistas negrodescendentes que realizaram trabalhos em outras localidades do Brasil na mesma época, como são os casos do paulista Jesuíno Francisco de Paula Gusmão (1764-1819) e do baiano José Teófilo de Jesus (1758-1847). Apesar do predomínio de temática canalizada no catolicismo, encontramos na produção de Teófilo de Jesus uma exceção. Apresentaremos uma proposta de abordagem de uma de suas alegorias dos continentes, a referente ao continente africano (Figura 1), seguida de alegoria do mesmo continente (Figura 2), pintada pelo italiano Giovanni Battista Tiepolo (1696-1770): 


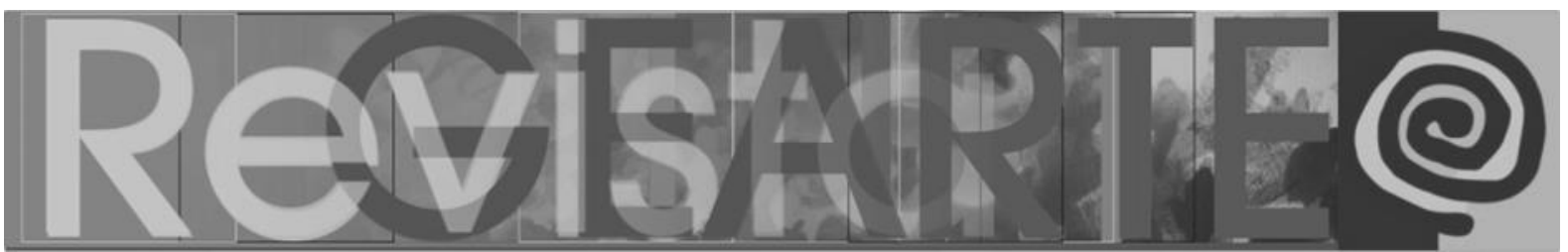

Figura 1 - José Teófilo de Jesus, Alegoria da África, s/d, óleo sobre tela, 65 × $82 \mathrm{~cm}$

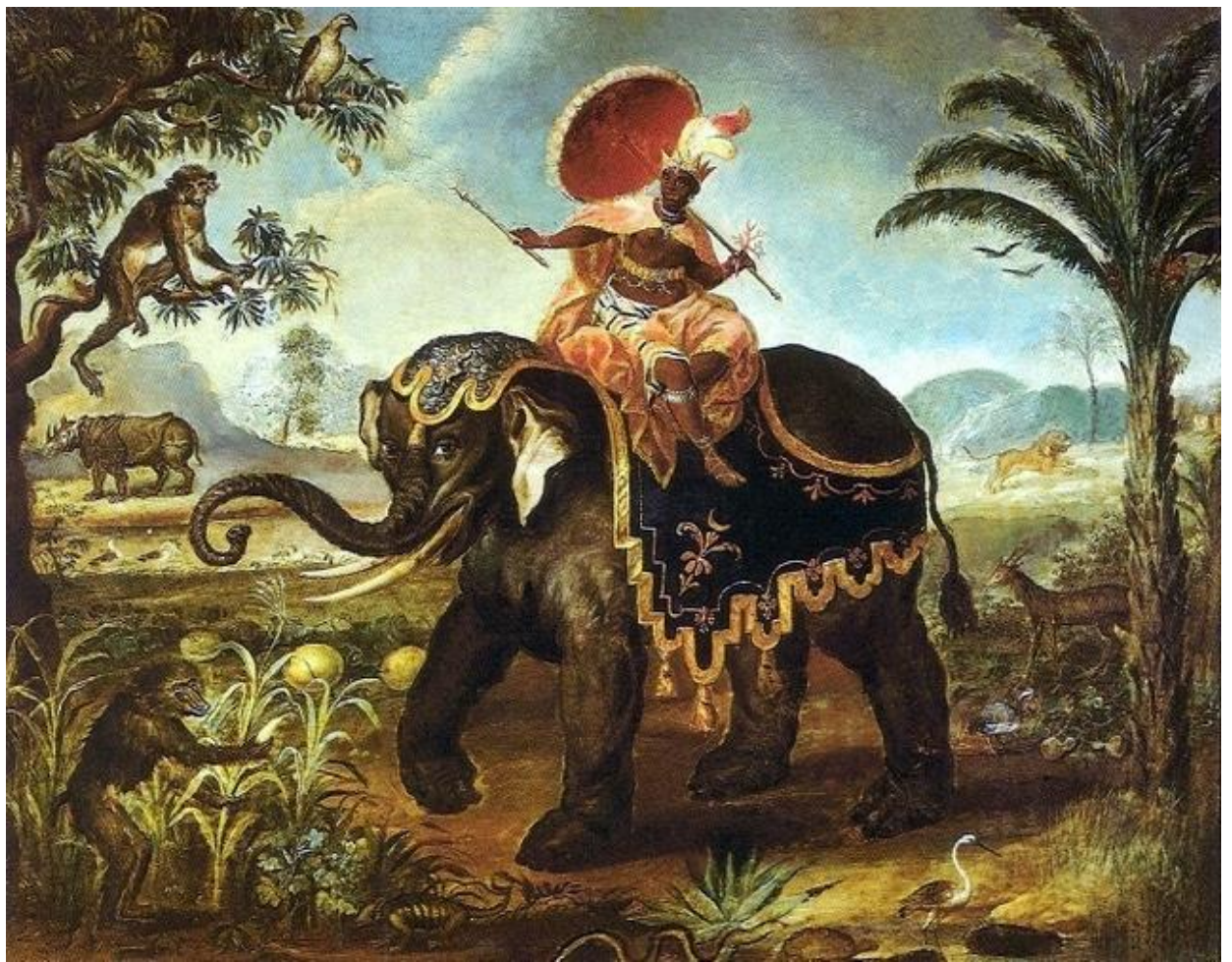

Fonte: <https://pt.wikipedia.org/wiki/Jos\%C3\%A9_Te\%C3\%B3filo_de_Jesus>. Acesso em: 10 fev. 2019.

Figura 2 - Giovanni Battista Tiepolo, Alegoria da África: homem com camelo, detalhe do afresco Apollo e os continentes, na escadaria do Würzburg Residenzschlos, $1752-3,1900 \mathrm{~cm} x$ $3050 \mathrm{~cm}$ (dimensões do afresco inteiro)

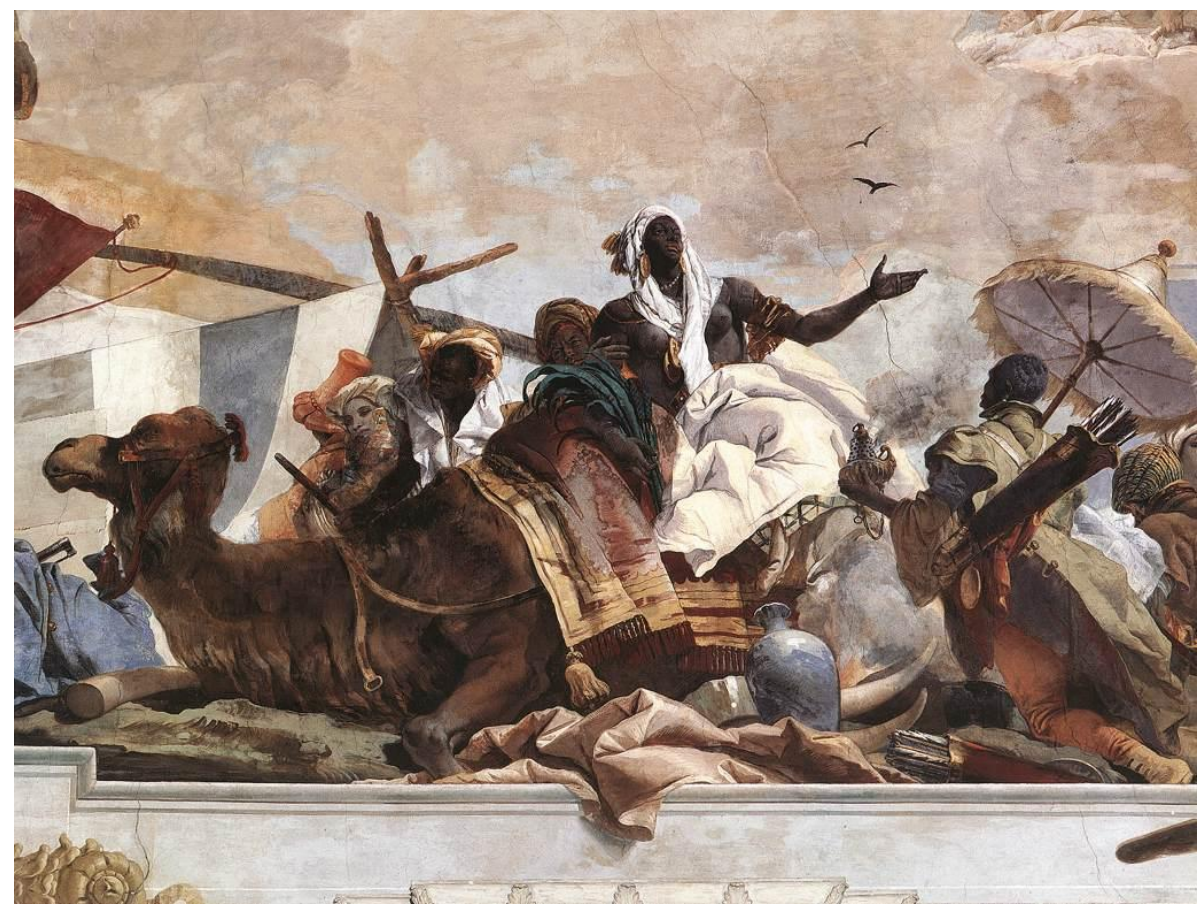

Fonte: <http://thehealingpowerofimages.blogspot.com/2012/07/>. Acesso em: 10 fev. 2019.

SANTOS, Renata Aparecida Felinto dos. A pálida História das Artes Visuais no Brasil: onde estamos negras e negros? 353

Revista GEARTE, Porto Alegre, v. 6, n. 2, p. 341-368, maio/ago. 2019.

Disponível em: http://seer.ufrgs.br/gearte 


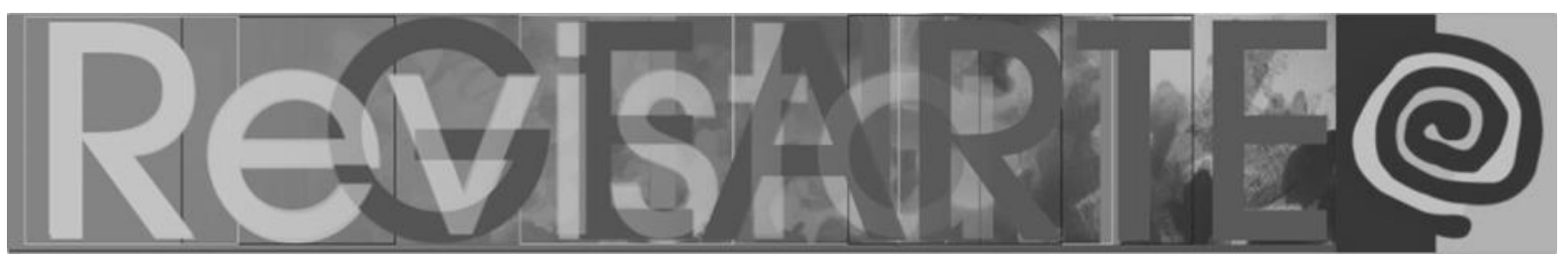

Apesar da distância formativa e geográfica, a temática da alegoria era um gênero comum entre os séculos 16 e 19, e nestes casos, consistia em representar as riquezas de cada continente com destaque para seu gentio, fauna e flora devido a novidade que representava o conhecimento do Velho Mundo (Europa) em contraste com as novidades que apresentavam as terras recém conhecidas pelos exploradores europeus (Américas, Ásia e África). Ambas as obras que selecionamos são produções que se ambientam no movimento barroco resguardos os contextos de desenvolvimento dessa escola artística no Brasil e na Itália.

No caso de Tiepolo, destacamos aqui um detalhe de afresco que retrata todos os continentes $^{9}$, e que exibe a África conhecida até então pelos europeus. Identificamos a cena como localizada entre a região do Sahel e do Norte do continente por vários elementos como: o camelo, animal que realizava o transporte de pessoas e de mercadorias nas caravanas comerciais; pessoas cujas as vestimentas indicam a inserção na cultura islâmica que é comum neste região; valiosos produtos de escambo como o tapete que reveste o lombo do camelo, as cerâmicas, os marfins de elefantes, objetos que, dentre outros, serviam como moeda. A composição triangular escolhida por Tiepolo é característica do período barroco e culmina com a cabeça da mulher que representa África em seu topo e ao centro, cabeça que esta revestida por um lenço branco e os braços adornados por dourados braceletes apesar de seminua, uma mulher que orgulhosamente apresenta as riquezas de seu continente.

Já a composição da pintura de Teófilo de Jesus, remonta a tradição dos pintores holandeses que estiveram no Brasil no século 17, na região de Pernambuco, como a pintura de Albert Eckhout (1610-1665), representando uma mulher africana, de 1641. A sua África está, portanto, ladeada de um parca vegetação, talvez para sinalizar o clima seco em algumas regiões do continente, juntamente com alguns animais de pequeno

9 "A obra foi encomendada pelo príncipe-bispo Karl Philipp Greiffenklau, que reinou de 1749 a 1757, quando morreu. Embora muito rico, o príncipe foi uma figura de menor importância histórica, imortalizado por Tiepolo com imensa inventividade e confiança como se fosse um herói poderoso", Conheça Alegoria dos Planetas e Continentes, de Giambattista Tiepolo. Universia Brasil. Em destaque. 20 jun. 2012. Disponível em: http://noticias.universia.com.br/destaque/noticia/2012/06/20/944346/conheca-alegoriados-planetas-e-continentes-giambattista-tiepolo.html. Acesso em: 10 fev. 2019. 


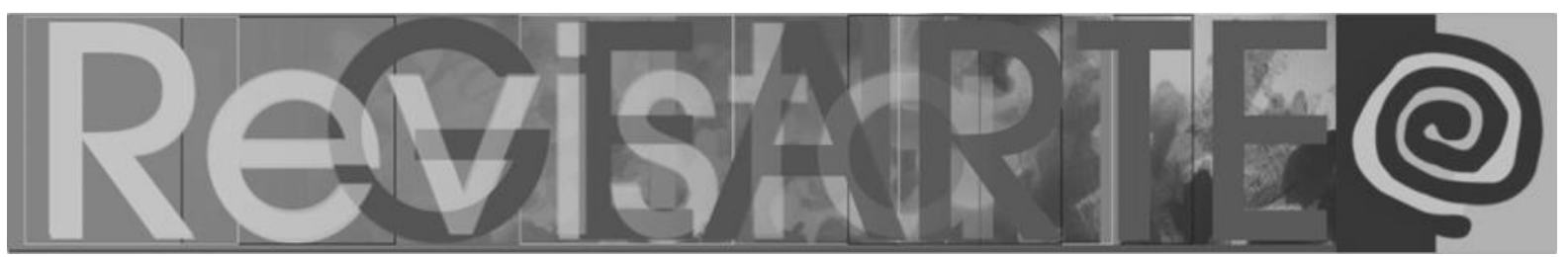

porte que estão nas copas das árvores e no chão. Ao fundo também estão animais desse continente de maior porte como o rinoceronte e o leão, que deveriam causar enorme curiosidade, pois que outros pintores os representaram. A suavidade das pinceladas conjugadas à ação do tempo quase apresentam alguns animais extremamente integrados à vegetação de forma que quase desaparecem no conjunto da composição.

A África de Teófilo de Jesus também é representada por uma mulher seminua, neste caso, sentada sobre o elefante revestido por um tecido que se assemelhada a um brocado, tecidos com motivos ricamente bordados em fio de ouro ou dourado. Sua África, também ao centro da composição desfila majestosa e, o próprio elefante nos mira como que ciente do nosso olhar.

As duas Áfricas, de Tiepolo e de Teófilo de Jesus possuem convergências em suas representações. Os detalhes em dourado que adornam os corpos dessas mulheres ou seus entornos denunciam a fascinação que os metais preciosos causavam nos exploradores europeus e, ao mesmo tempo, a esperança de encontrálos em abundância no continente. Na África de Tiepolo são as mercadorias que chegam à Europa por meio do comércio transaariano que dominam a cena, enquanto na de José Teófilo já há mais informações acerca do continente no qual os europeus, especialmente portugueses, tentavam penetrar mas que, entretanto, tinha na fauna $e$ na flora dois obstáculos. Ambas as representações apresentam corpos desnudos o que alimenta o imaginário ocidental acerca de uma sensualidade e sexualidade pulsantes nas populações do continente, pois, em comparação com europeus, alguns desses povos por estarem em localidades muito quentes e não serem cristãos não cultivavam os mesmos tabus em relação aos corpos nus. Por fim, ressaltamos que essas duas Áfricas são retratadas com um espírito soberbo e altivo que difere das qualidades que o senso comum hoje atribui ao continente berço da humanidade.

Para além dessa análise mais comparativa, expandindo as possibilidades de compreensão da história das artes visuais, seria oportuno apresentar o que ocorria em parte da África neste momento cronológico, para além da fértil imaginação dos dois artistas. Se considerarmos esse pequeno recorte cronológico ao qual nos 


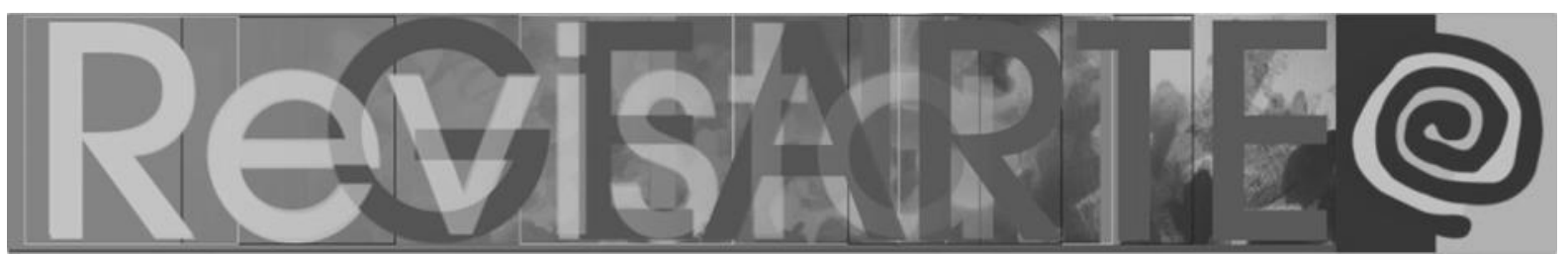

referimos sobre o barroco na Itália e no Brasil, podemos, por exemplo, apresentar uma significativa produção do país que hoje conhecemos como Nigéria: a do Império do Benim, também conhecido como Império Edo.

Estima-se que o Império do Benim tenha sido fundado por volta do século 10 e existido e resistido até o fim do século 19, quando foi invadido e saqueado por britânicos. Parte considerável das obras de arte que adornavam o palácio real e que também narram os feitos históricos dessa secular população da África Ocidental encontram-se atualmente no Museu Britânico, tais quais as placas comemorativas fundidas em uma liga que mescla bronze e latão.

Inclusive, mencionar e mesmo aprofundar na observação e estudo dessas obras de arte do antigo Império do Benim é fundamental para compreender estilisticamente parte da estética da estatuária em madeira produzida no Brasil do fim do século 19 para início do século 20, que demarca os estudos do que chamamos de arte afro-brasileira e que de forma um tanto quanto cientificista foi pioneiramente estudada e registrada pelo médico baiano Raimundo Nina Rodrigues $(1862-1906)^{10}$.

A partir da abertura da já mencionada Academia Imperial de Belas Artes, esse fazer artístico que, anteriormente a ela no Brasil ocorria via corporações de ofício e do compartilhamento de informações entre mestres e aprendizes, passa ser estruturado de outra maneira que "valida" o ofício de artista:

Se antes sua formação era realizada de maneira anônima, e ele confundido com o artesão e retirado dos estratos mais baixos da população, a partir da criação da Academia, era de se esperar que o artista começasse a ser pensado como um profissional ao qual estaria reservada uma formação erudita, propícia a capacitá-lo no sentido de fazê-lo interagir no processo de constituição de uma cultura visual superior, onde à mera perícia artesanal deviria estar aliado um saber intelectual, consciente da tradição, ou das tradições artísticas e culturais do momento. ${ }^{11}$

10 A esse respeito ler o artigo do mesmo médico RODRIGUES, Raimundo Nina. As bellas-artes nos colonos pretos do Brazil: a esculptura. Kósmos: revista artistica, scientifica e litteraria. Rio de Janeiro, v. 1, n. 1, p. 11-16, ago., 1904.

11 GONZAGA DUQUE, Luiz. A arte brasileira. Campinas, SP: Mercado de Letras, 1995. (Coleção Arte: Ensaios e Documentos). p. 13. 


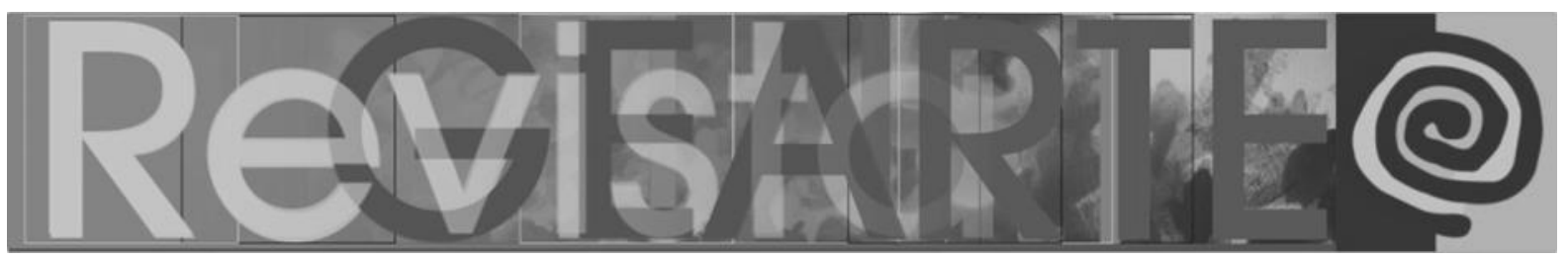

O que significa que além dos artistas terem maior autonomia em relação aos temas que retratavam que passaram a extrapolar as demandas e temáticas da Igreja Católica, ser considerado artista também consistia em ter uma formação mais específica e normatizada. Essa exigência que se sedimenta ao longo dos anos, que impõem uma estrutura de formação comum a todas as pessoas que desejavam serem artistas, evidentemente que também aparta uma parcela da população dessa realização e, de modo geral, essa população é negradescenente.

É sabido que a Academia Imperial de Belas Artes teve artistas negros, especialmente com a transição de Império para República em 1889, quando a Academia é rebatizada como Escola Nacional de Belas Artes. Alguns nomes e obras chegaram até nós como os dos irmãos Timótheo da Costa, Emmanuel Zamor (18401917), Antônio Rafael Pinto Bandeira (1863-1896), Estevão Roberto da Silva (18441891), dentre tantos outros registrados pelo historiador e crítico de história da arte brasileira Luiz Gonzaga Duque-Estrada (1863-1911).

Contudo, a sobrevivência de alguns nomes não significa que esses artistas visuais, em sua maioria pintores, foram todos reconhecidos em vida, alguns passaram por enormes dificuldades para concluir seus estudos devido às questões financeiras, lembremos que parte deles iniciaram suas formações durante a vigência da escravidão como sistema de trabalho e que, nos pós-abolição (1888), não houve nenhuma espécie de política pública que visasse a incorporação da população exescravizada numa perspectiva de acessos. Isto significa que estamos tratando de exceções.

E ainda que inseridos neste panorama, alguns deles tiveram certa visibilidade no que tange a possuir trabalho e a possibilidade de usufruir de uma estrutura proporcionada pela Escola Nacional de Belas Artes, como os prêmios de viagem ao exterior, por exemplo. Dentre esses artistas, destacamos a curta trajetória do fluminense Arthur Timótheo da Costa (1882-1922), que realizou inúmeros trabalhos voltados às artes decorativas com seu irmão João Timótheo da Costa (1879-1932), foi premiado com viagem à Europa para aprimorar seus estudos artísticos no ano de 


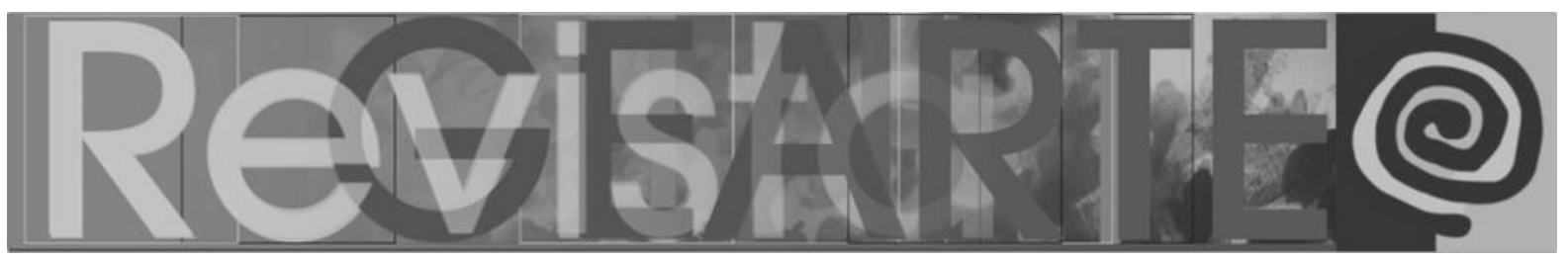

1907, pela Exposição Geral de Belas Artes e, por meio de suas pinturas, apresentou inúmeras experimentações e incorporações pictóricas com as quais teve contato nesta viagem.

Pôde estudar e apreender as transformações modernas que se iniciam com o impressionismo, movimento iniciado em 1860 e sendo o pontapé do modernismo que estendeu-se a movimentos artísticos como o fauvismo, expressionismo dentre outros cujas relações pictóricas e formais são identificáveis nas produções de Arthur Timótheo.

Tratar desse posicionamento artístico e estético que Arthur Timótheo agregou às suas pesquisas em pintura é reconhecer que esse artista se antecipou às premissas colocadas pelos modernistas brasileiros, o que o coloca como um prémodernista, ou modernista antes mesmo da exposição do lituano Lasar Segall (18891957), ocorrida em 1913 de base expressionista; antes de Anita Malfatti (1889-1964), cuja exposição em dialoga com a mesma escola expressionista e é considerada a primeira exposição modernista de uma artista visual no Brasil; ou ainda, anterior ao acontecimento da Semana de Arte Moderna de 1922, da qual participaram importantes nomes das artes, de forma geral.

Reparem também que o reconhecimento de ser pioneiro ou pioneira, de ter uma produção de arte relevante ou não, de formar um público que aprecie e adquira um certo tipo de obra, fundamentalmente consiste na exposição do que se produziu, no mostrar, no exibir. O lugar de exposição é o de legitimação, é o de registro. Não temos conhecimento de neste início de século 20, ter havido uma exposição de Arthur Timótheo que reunisse as pinturas decorrentes da ampla pesquisa que encaminhou e, com isso, há um apagamento histórico de seu empenho em "modernizar" a pintura brasileira. 


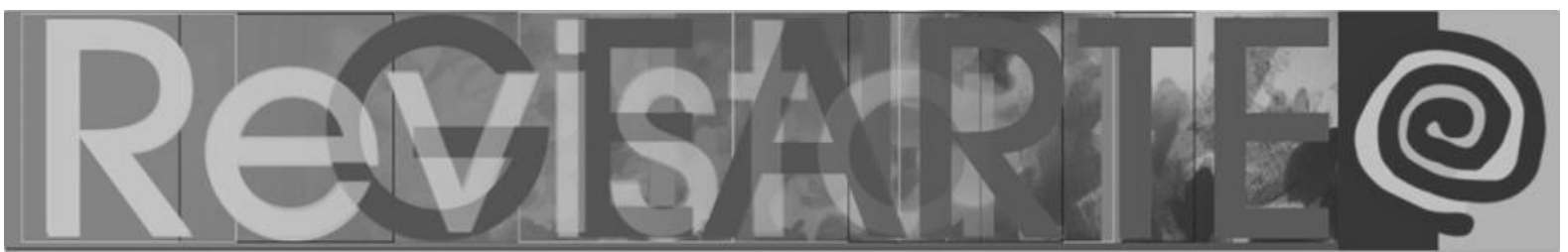

Figura 3 - Arthur Timótheo da Costa, Sem título, s/d, óleo sobre tela, $36 \mathrm{~cm}$ x $34 \mathrm{~cm}$. Coleção particular

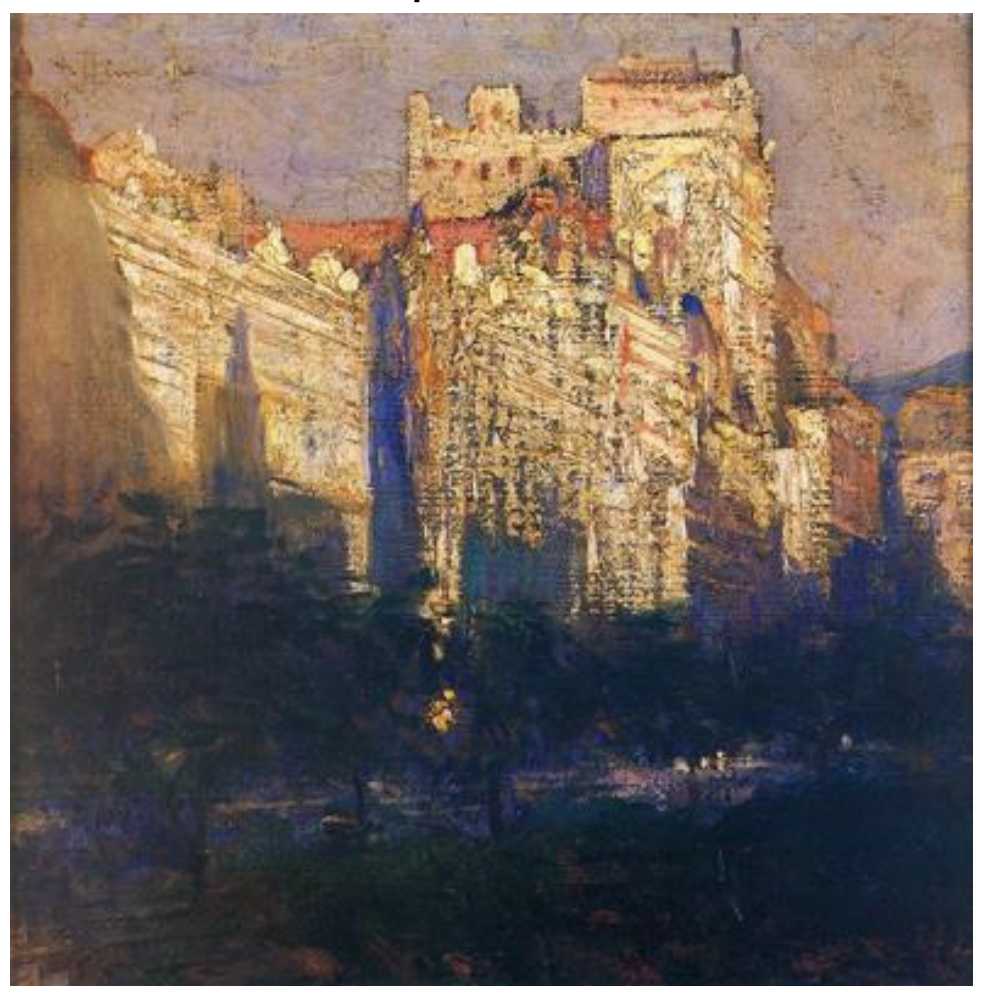

Fonte: Disponível em: <http://enciclopedia.itaucultural.org.br/obra3318/sem-titulo>. Acesso em: 11 fev. 2019.

Figura 4 - Oscar-Claude Monet, as 18 telas que retratam a Catedral de Rouen de um mesmo ponto de vista, 1892, óleo sobre tela.
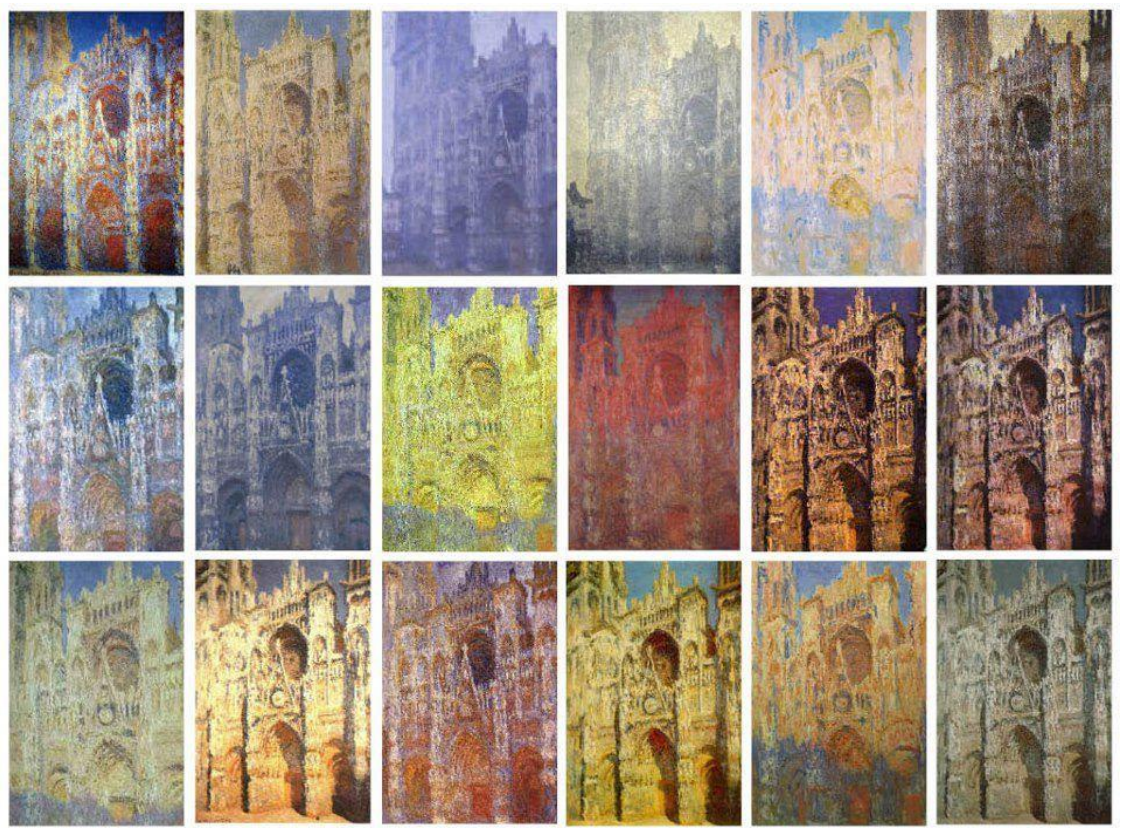

Fonte: <https://i.pinimg.com/originals/5a/91/c4/5a91c47ed2fd27b3e8f5d26eea42b9e8.jpg>, Acesso em: 03 mar. 2019. 


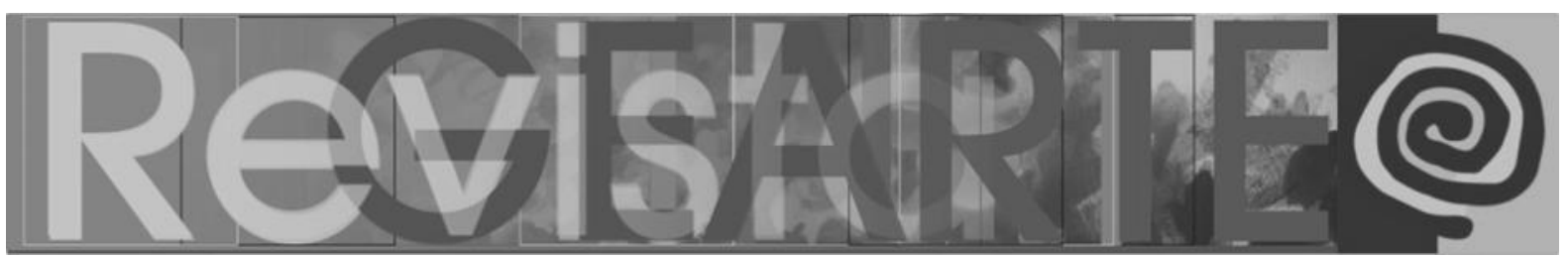

Em uma de suas pinturas sem título e sem data, do início do século $X X$, na qual o pintor fluminense retrata uma igreja (Figura 3), é visível a referência ao processo de pesquisa de Claude Monet (1840-1926), acerca da interferência da luz em nossa percepção cromática, cujos resultados obtidos pelo pintor francês estão registrados nas 18 pinturas que realizadas a partir da Catedal de Rouen (Figura 4). Na pintura de Arthur Timótheo, os detalhes arquitetônicos que explodem em claridade e que não possuem nitidez por este motivo, estão em diálogo com as pinturas de Monet, especialmente as que exibem a luz difusa e amarelada de final de tarde.

São inúmeras as pinturas de Arthur Timótheo que expressam o seu interesse e dedicação à incorporação de um pensamento menos acadêmico da pintura. $O$ fato de tratarmos de um homem negro trabalhador das artes visuais, que sobrevivia de seu fazer sem estar inserido em determinados círculos, o coloca à margem de alguns acontecimentos e, não ser visto é não ser lembrado, em qualquer época. Se em 2019 não é simples ser um artista negro, o que o seria em 1919? Arthur Timótheo faleceu aos 41 anos, internado no Hospício dos Alienados do Rio de Janeiro com o diagnóstico de demência paralítica ${ }^{12}$, mas aqui tentamos dignificar a sua iniciativa e colocá-lo em seu devido lugar de modernista.

Como uma forma de expandir esses estudos sobre o modernismo a partir do impressionismo, também é importante inserir as diversas pintoras impressionistas que atuaram neste mesmo período como a estadunidense Mary Cassat (1843-1926), que levou para as temáticas impressionistas o ambiente doméstico, especialmente as relações entre mulheres mães e suas crianças, alternando as cenas extremamente doces e de carinho com os momentos de cansaço e exaustão que também abarcam a maternagem.

Como uma terceira e última proposta de abordagem em história das artes visuais do Brasil numa perspectiva decolonial, ou que se pensa nesse caminho,

12 Arthur Timótheo da Costa. Museu Afro Brasil. Índice Alfabético. Disponível em http://museuafrobrasil.org.br/pesquisa/indice-biografico/lista-de-biografias/2014/12/02/arthurtimotheo-da-costa. Acesso em: 10 fev. 2019. 


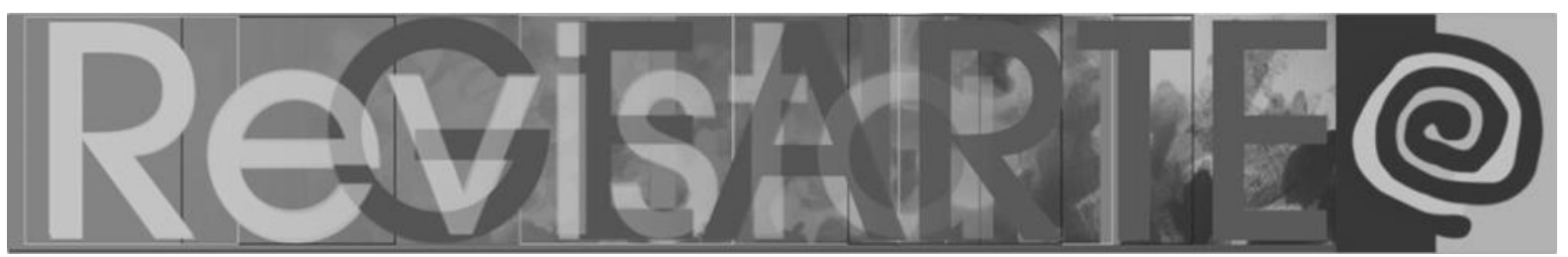

insistimos no modernismo, mas agora propondo uma reflexão mais sociológica acerca do que exibimos e do que ocultamos durante tanto tempo nesses estudos. Para tanto, trazemos as pinturas da paulistana Tarsila do Amaral e da mineira Maria Auxiliadora da Silva (1935-1974), mulheres que com pouco mais que geração de diferença entre as datas de nascimento, tiveram trajetórias absolutamente opostas no campo das artes, uma de origem extremamente privilegiada e a outra de origem totalmente vulnerável; uma que tinha posses familiares que the permitiram estudar arte com os melhores pintores no exterior e a outra que teve que abandonar os estudos criança para auxiliar no orçamento familiar e retomou o seu processo de alfabetização já adulta; uma que explorou tematicamente a cultura brasileira de matriz negra e popular de seu lugar de espectadora e outra que a aborda como protagonista que participa de folguedos. Os abismos biográficos entre as duas artistas são gritantes, isso não deprecia as produções de nenhuma, entretanto, revela a perversidade histórica de nossa sociedade.

De Tarsila do Amaral trazemos a tela $A$ Negra $^{13}$ e de Maria Auxiliadora da Silva, a tela Autorretrato com anjos ${ }^{14}, 1972$.

A Negra, pintura realizada no ano de 1923, quando a artista estava em em Paris para aprimoramento artístico, onde teve aulas com artistas importantes do contexto das vanguardas europeias, como Fernand Léger (1881-1955), que se insere na escola cubista. Inclusive consideramos que há uma enorme herança formal do modo de pintar de Léger nos primeiros trabalhos modernistas de Tarsila, especialmente naquelas pinturas que retratam o crescimento e industrialização da cidade de São Paulo como a tela de mesmo nome de 1924, ou nas que se inspiram na cultura popular, nos seus contos e nas paisagens rurais como a tela $A$ Lua, de 1928, recentemente adquirida pelo MoMA, de Nova lorque.

13 Tarsila do Amaral, A Negra, 1923, óleo sobre tela, $100 \times 81,3 \mathrm{~cm}$. Coleção MAC/USP (SP). Disponível em: <http://enciclopedia.itaucultural.org.br/obra2322/a-negra>. Acesso em: 03 mar. 2019.

14 Maria Auxiliadora da Silva, Autorretrato com anjos, 1972, óleo sobre tela, $63,5 \times 45 \times 3 \mathrm{~cm}$. Coleção Silvia e Mario Gorksi. Disponível em: <http://www.infoartsp.com.br/agenda/maria-auxiliadora-vidacotidiana-pintura-e-resistencia/>. Acesso em: 03 mar. 2019. 


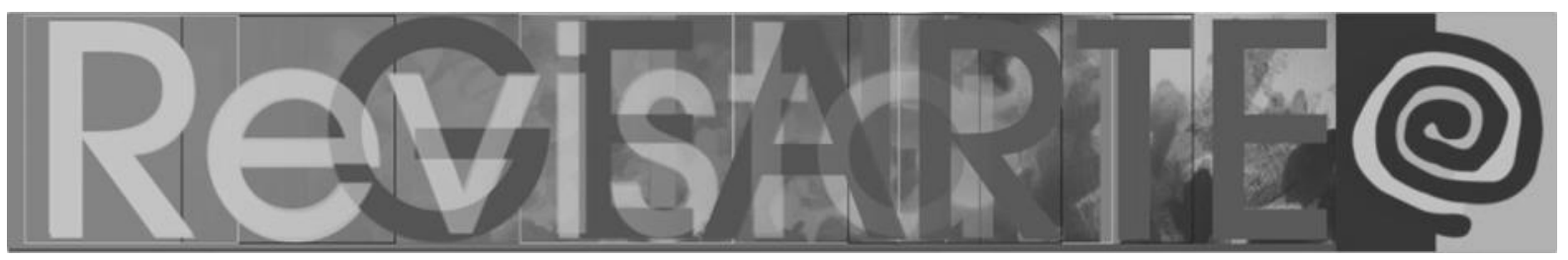

Tarsila percebe que no ambiente parisiense da década de 1920 existia toda um interesse da classe artística por conhecer um conjunto de manifestações culturais que foram agrupadas como "arte e cultura negras", a arte de África e da diáspora africana que chegava à Europa por meio, principalmente, de esculturas provenientes dos violentos contatos dos neocolonialistas com as populações africanas sob forças desproporcionais das chamadas potências. Mais do que esculturas também chegavam fotografias, filmes, músicas, relatos, não somente de e sobre a África, mas também das culturas afro-americanas (estamos expandindo o entendimento de afroamericana para todas as três Américas). Assim, de forma sintética devido à natureza dessa escrita, jazz (Estados Unidos da América), candombe (Uruguai), candomblé (Brasil), tango (Argentina), dentre muitas outras expressões culturais e artísticas afroamericanas tornam-se foco de interesse das elites americanas, pois que demarcam a "novidade" ante à herança artística e cultural hegemônica, mas também a indelével resistência dessas populações que desterradas e escravizadas se reinventaram, se preservaram, sobreviveram em muitos aspectos via arte.

Assim, apesar das muitas leituras da pintura $A$ Negra que podemos realizar hoje, na pintura de Tarsila ela representa o alcance e inserção no mercado de arte internacional, pois percebeu que havia um especial interesse pela temática negra. $A$ mulher que a pintora exibe na obra tem como referência a ama-de-leite que acompanhou a própria artista e da qual existe uma fotografia que a retrata tal qual a posição da figura da pintura, especialmente as posições corporais da mulher da pintura e da mulher da fotografia.

Existe uma leitura romantizada, bem ao modo brasileiro, de não encarar o colonialismo, a escravidão, o racismo e a marginalização das pessoas negras, que interpreta a obra $A$ Negra como um elogio amoroso da artista à mulher que fora sua cuidadora. Porém, muito provavelmente, essa relação de afeto entre Tarsila e a anônima da fotografia, talvez não fosse fundada numa afetividade bilateral.

Quando a pintora despe a figura da mulher - que na fotografia original que the serviu de referência está vestida - ela despe-se também, mostrando-se como uma 


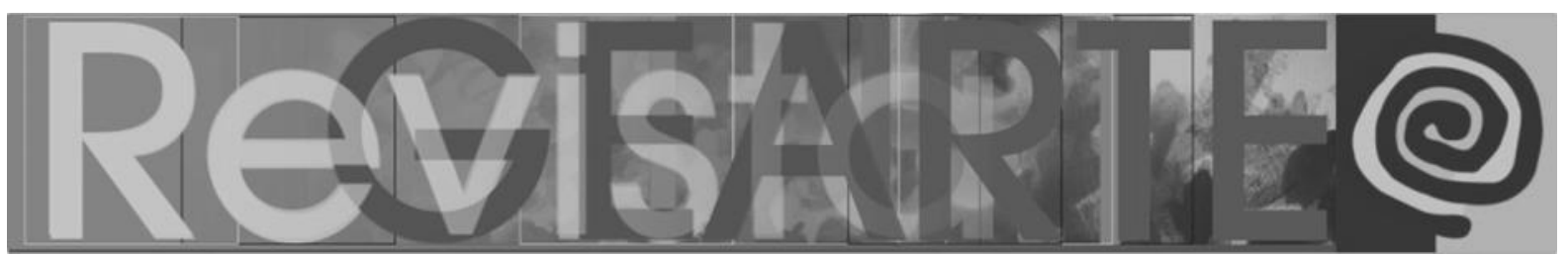

mulher que não consegue humanizar aquela que the conferiu dedicação e educação. Transforma essa mulher vestida numa mulher nua e extremamente embrutecida na qual acentua traços faciais próprios do fenótipo negro; retira-lhe também as vestimentas e os cabelos. Exotiza essa mulher, de maneira que se alinhe à concepção que se forjava sobre populações e pessoas negras-africanas, que é a de selvagens, exóticas e incivilizadas. Segundo o crítico de arte Silas Martí:

Ela quase transborda do quadro, os dedos dos pés e o alto da cabeça roçando os limites da pintura. O seio enorme, que pende sobre os braços cruzados, e os lábios carnudos fazem dessa figura despida uma mulher superlativa, com ar de fera enjaulada ou mucama violentada. ${ }^{15}$

Tarsila expropria essa mulher de sua humanidade e identidade, ela passa ser somente $A$ Negra, por mais que tivesse um nome, isso diz muito sobre como as mulheres negras são entendidas e tratadas socialmente no Brasil.

Essa concisa análise do que está nas entrelinhas da leitura da obra A Negra, é essencial para observarmos, entendermos e valorizarmos biografias e produções de artistas visuais como Maria Auxiliadora e, neste caso, percebermos que toda a sua obra se dirige para o lado oposto que é o de conferir humanidade às populações excluídas, bem como às suas práticas mais corriqueiras, igualmente como confere humanidade a si também.

Maria Auxiliadora não teve tempo de estudo com artistas renomados, ao contrário, cedo a sua família mudou-se de Minas Gerais para São Paulo, do ambiente rural para o urbano, e com o tempo a criança cedeu seu tempo para, primeiramente, trabalhar como doméstica e depois costureira. Paralelamente teve uma educação informal em artes visuais a partir dos aprendizados em costura e bordado com sua mãe, dos desenhos que realizava de forma livre e de todo um ambiente familiar no qual conviveu com escultores, poetas e pintores. João Cândido (1933-), é pintor, irmão

15 MARTÍ, Silas. MoMA expõe obras de Tarsila do Amaral nos anos 1920, como "A Negra". Arte. Folha de São Paulo. 08 fev. 2018. Disponível em https://www1.folha.uol.com.br/ilustrada/2018/02/momaexpoe-obras-de-tarsila-do-amaral-nos-anos-1920-como-a-negra.shtml. Acesso em: 03 mar. 2019. 


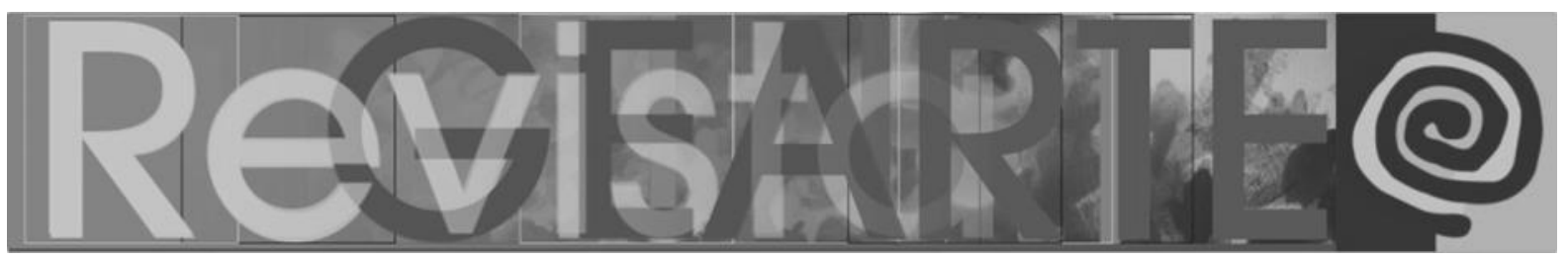

de Maria Auxiliadora e encontra-se em atividade tendo recentemente aberto seu ateliê em São Paulo.

Para além da família, ela também teve uma formação em cultura afro-brasileira a partir de sua vivência com o grupo de artistas não-hegemônicos que expunha na Praça da República e com a Família Trindade, na qual a figura de Raquel Trindade (1936-2018), também pintora dentre outras ocupações, incentivou-lhe a pintar. Assim fortalecida, Maria Auxiliadora, em 1967, resolveu dedicar-se somente à pintura registrando tanto as suas lembranças de infância, que retratavam as festas da roça, mas também todo um imaginário afro-brasileiro e popular com o qual teve contato a partir de sua vivência com várias pessoas já inseridas no artivismo ${ }^{16}$.

Vendeu obras em vida, teve o reconhecimento de críticos como Mário Schenberg (1914-1990), que a introduziu num círculo de contatos que projetou a sua carreira no Brasil e no exterior, sem que com esse feito conseguisse viver confortavelmente de seu trabalho como artista.

Dentre as suas várias pinturas, Autorretrato com anjos é o reverso da pintura $A$ Negra, de Tarsila do Amaral. Substitui a mulher negra no lugar de objeto observado para o objeto retratado a partir da mulher negra como protagonista que se autorretrata em seu ofício. Se $A$ Negra apresenta uma mulher negra nua e destaca as deformações ou adaptações do corpo à condição de quem amamentou muitas crianças, ao focarmos no seio longo caído à frente do braço, Autorretrato com anjos apresenta uma mulher negra totalmente vestida em trajes rendados, cujos detalhes vermelhos da blusa e da calça ornam com o turbante nos cabelos. Turbante esse que ainda que estivesse em voga nos anos de 1970 como acessório de moda, também acena para uma busca pela cultura afro-brasileira, que encontramos nos temas de inúmeras pinturas de Maria Auxiliadora.

No seu autorretrato a artista está também pintando, neste caso uma cena rural que remonta ao passado e origens de sua família, no lugar onde se planta, se cultiva

16 Artivismo é uma palavra resultante da mescla de artista e ativista. 


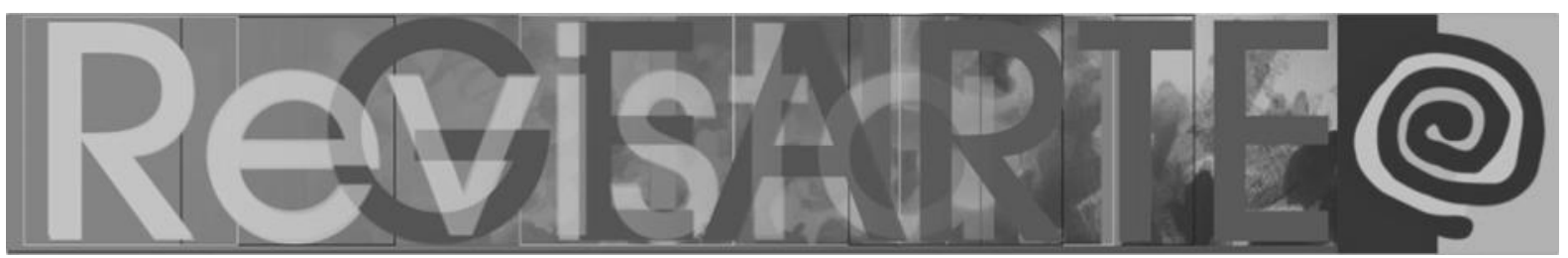

e se colhe, no lugar onde os pés tocam a terra. Reparem também que a artista se autorretrata descalça, e apenas os pés desnudos, apenas o que reconecta com a ancestralidade.

Desse modo, as duas pinturas que retratam mulheres negras têm suas importâncias na história das artes visuais considerando seus contextos de criação. Porém, uma apresenta uma visão que exotiza a mulher negra, enquanto a outra apresenta a mulher negra que se emancipa; uma recoloca o corpo dessa mulher no lugar de exposição, sujeito à observação de outrem, já o outro é a mulher negra quem observa e pinta o que é observado; na primeira a negra é objeto, na segunda ela é protagonista que se registra no mundo. São curtas comparações de enorme profundidade do ponto de vista histórico, porque se à mulher negra lhe foi negada qualquer possibilidade de ascensão socioeconômica e, consequentemente, em outras áreas da vida, é essa mesma mulher que rompe com a máscara que silencia, com as correntes que imobilizam e se permite outras existências, que rompem com o que o imaginário, a representação por meio de parâmetros ocidentais Ihe impunha.

\begin{abstract}
O conjunto das obras de Auxiliadora é não apenas um testemunho de superação de obstáculos históricos, sociais e culturais, mas, sobretudo, uma forma de sobrevivência à qual se agarrou desde a infância, e uma maneira de se comunicar, de criar, de existir no mundo.

Da infância à vida adulta, seu amor pela arte é notório; foi por ela que suspirou em vida, e com quem se uniu numa intensa relação de processo criativo entre os anos de 1967 até 1974, quando fez sua passagem. Foi com a arte que dividiu a vida e o prazer de pintar de tudo um pouco. Habituadas/os que estamos a determinados padrões que nos enrijecem a alma, esquecemo-nos de tirar o véu "branco-europeu-ocidental-hétero-exato-linear" dos olhos e oferecer um cafuné ao olhar. ${ }^{17}$
\end{abstract}

Cremos na profundamente que o estudo comparativo entre as biografias de artistas visuais, as suas obras, os contextos que lhes permitiram (ou não) o seu progresso enquanto profissionais da arte, articulados às importâncias que encontramos nestas produções por meio de suas observações, leituras, interpretações, e correlações com o mundo no qual estamos são imprescindíveis para

17 SANTOS, Renata Aparecida Felinto. A Forma como sobrevivência: dengo para o olhar. In: PEDROSA, Adriano; OLIVA, Fernando (Orgs.). Maria Auxiliadora: vida cotidiana, pintura e resistência. São Paulo: Editora MASP, 2018. 


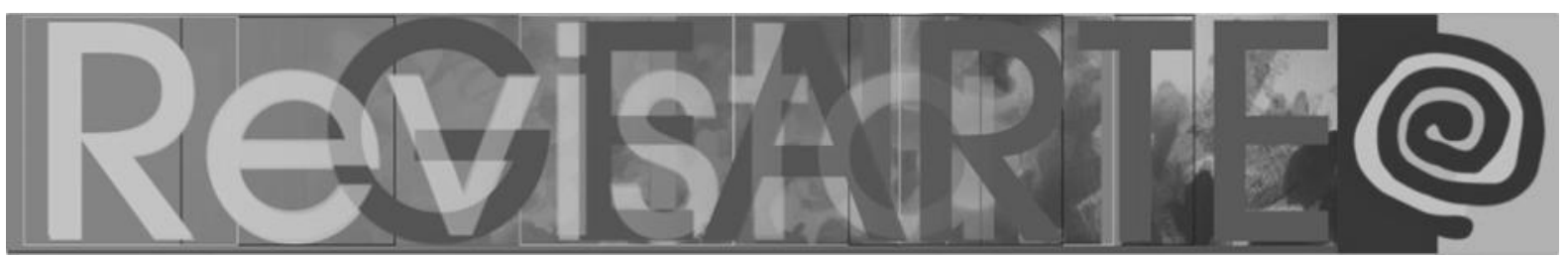

a escrita da história das artes visuais, a reflexão crítica acerca desses objetos de arte e o que os mesmos são, o que representam na perspectiva do crescimento e desenvolvimento humanos. Obras de arte existem porque pessoas que as produzem existem. Obras de arte servem à nossa existência e não deveriam serem estudadas apartadas da história das sociedades humanas.

Neste momento é hora de desvelarmos a história das artes visuais, bem como de estudarmos as histórias das humanidades sem amenizarmos, romantizarmos, omitirmos acontecimentos, por mais desafiador que seja confrontarmos o passado histórico. E isso deve ser feito por todas as pessoas em todos os lugares. Essa desconstrução, "descolonização do conhecimento" - numa referência ao texto uterino de Grada Kilomba ${ }^{18}$ - é urgente e devemos refletir e exercitar sobre como a faremos; apresentando que não temos vencedores e vencidos, como nos foi ensinado; que não existe um conceito de belo universal, que possa, de fato, ser atribuído às obras criadas por populações tão diversas; que as obras-primas europeias não são superiores às obras-primas de outras populações.

A história das artes visuais no mundo e no Brasil não é pálida. A multiplicidade de cores transborda os limites dos objetos de arte, dos desenhos, pinturas, gravuras, esculturas, modelagens, fotografias, performances, vídeos, instalações, construções, o que quer que chamemos de obra de arte é imaginado e materializado por gente, e queremos saber e ver as cores de todas as gentes que têm se inscrito na história com suas existências e suas artes.

\section{Referências}

Arthur Timótheo da Costa. Museu Afro Brasil. Índice Alfabético. Disponível em http://museuafrobrasil.org.br/pesquisa/indice-biografico/lista-de-biografias/2014/12/02/arthur-timotheoda-costa. Acesso em: 10. fev. 2019.

Arte e a Lei de Diretrizes e Bases. Portal da Educação. Pedagogia. Disponível em: https://www.portaleducacao.com.br/conteudo/artigos/educacao/arte-e-a-lei-de-diretrizes-ebases/36090. Acesso em: 10 jan. 2019.

18 KILOMBA, Grada. Descolonizando o conhecimento. Instituto Goethe. Tradução Jéssica Oliveira. Disponível em http://www.goethe.de/mmo/priv/15259710-STANDARD.pdf. Acesso em: 03 mar. 2019. 


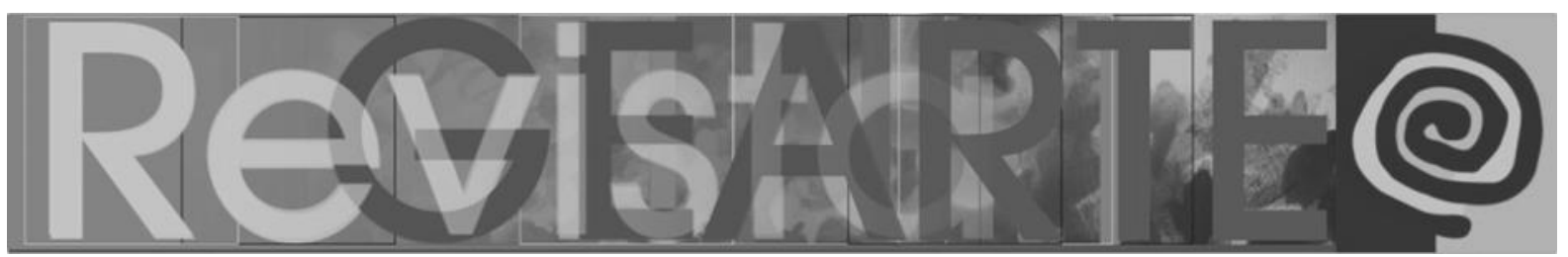

Perícia conclui que Dilma não participou de pedaladas fiscais. O Globo. 27 jun. 2016. Disponível em http://g1.globo.com/jornal-nacional/noticia/2016/06/pericia-conclui-que-dilma-nao-participou-depedaladas-fiscais.html. Acesso em: 03 mar. 2019.

Conheça Alegoria dos Planetas e Continentes, de Giambattista Tiepolo. Universia Brasil. Em destaque. 20 jun. 2012. Disponível em: http://noticias.universia.com.br/destaque/noticia/2012/06/20/944 346/conheca-alegoria-dos-planetas-e-continentes-giambattista-tiepolo.html. Acesso em: 10 fev. 2019.

CARNEIRO, Sueli. Epistemicídio. Geledés. 04 set. 2014. Disponível em https://www.geledes.o rg.br/epistemicidio/. Acesso em: 03 mar. 2019.

CARDOSO, Bia. Feminisno interseccional. Que diabos é isso? (e porque você deveria se preocupar). Blogueiras Feministas. 24 jul. 2014. Disponível em https://blogueirasfeministas.com/2014/07/24/f eminismo-intersecional-que-diabos-e-isso-e-porque-voce-deveria-se-preocupar/. Acesso em: 03 mar. 2019.

DÁVILA, Jerry. Diploma de brancura: política social e racial no Brasil -1917-1945. São Paulo: Editora UNESP, 2006.

GONZAGA-DUQUE. A Arte Brasileira: ensaios e documentos. Campinas (SP): Mercado das Letras, 1995.

KILOMBA, Grada. Descolonizando o conhecimento. Instituto Goethe. Tradução Jéssica Oliveira. Disponível em http://www.goethe.de/mmo/priv/15259710-STANDARD.pdf. Acesso em: 03 mar. 2019.

MARTí, Silas. MoMA expõe obras de Tarsila do Amaral nos anos 1920, como 'A Negra'. Arte. Folha de São Paulo. 08 fev. 2018. Disponível em https://www1.folha.uol.com.br/ilustrada/2018/02/moma-expoeobras-de-tarsila-do-amaral-nos-anos-1920-como-a-negra.shtml. Acesso em: 03 mar. 2019.

PORTO, Gabriella. Democracia Racial. Infoescola. Disponível em: <https://www.infoescola.com/ sociologia/democracia-racial/>, acesso 04 mar. 2019.

RODRIGUES, Raimundo Nina. As bellas-artes nos colonos pretos do Brazil: a esculptura. Kósmos: revista artistica, scientifica e litteraria. Rio de Janeiro, v. 1, n. 1, p. 11-16, ago., 1904.

SANTOS, Renata Aparecida Felinto. A Forma como sobrevivência: dengo para o olhar. In: PEDROSA, Adriano; OLIVA, Fernando (Orgs.). Maria Auxiliadora: vida cotidiana, pintura e resistência. São Paulo: Editora MASP, 2018.

\section{Renata Aparecida Felinto dos Santos}

Doutora em Artes Visuais pelo Instituto de Artes da Universidade Estadual Paulista Júlio de Mesquita Filho, bolsista da CAPES e contemplada pelo PDSE pela mesma agência para 2015. É Mestre em Artes Visuais e Bacharel em Artes Plásticas pela mesma instituição. Licenciada em Artes pelo Programa Especial de Formação Pedagógica (Formação de Professores) do Centro Universitário Belas Artes de São Paulo. Especialista em Curadoria e Educação em Museus de Arte Contemporânea da Universidade de São Paulo. Professora Adjunta de teoria da arte no Curso de Licenciatura em Artes Visuais, Universidade Regional do Cariri/ CE. Coordenadora do Curso de Licenciatura em Artes Visuais/ URCA e do PIBID/ Artes Visuais/URCA. É pesquisadora do grupo de pesquisa Barroco Memória Viva do Instituto de Artes da Universidade Estadual Paulista/ SP. É líder do grupo de pesquisa NZINGA Novos Ziriguiduns Internacionais e Nacionais Gerados nas Artes Visuais. Conduz o Projeto de Pesquisa YABARTE pela Pró-Reitoria de Pós-Graduação e Pesquisa e o Projeto de Extensão de mesmo nome pela Pró-Reitoria de Extensão. Atua há 20 anos nas artes visuais, dos quais 10 foram dedicados à arteeducação em museus e instituições de arte e cultura tendo sido coordenadora do Núcleo de Educação do Museu Afro Brasil. Foi coordenadora e idealizadora autônoma de projetos de artes visuais e de educação que envolvem os temas das artes visuais, história da arte, culturas africanas e afro-brasileira, identidade, gênero a partir de convites de instituições como o SESC, SESI, Pinacoteca do Estado de São Paulo, ID Brasil, possui vários livros coordenados e publicados pelas editoras Fino Traço e DCL. Como artista visual, vem desenvolvendo trabalhos que relacionam arte, identidade e gênero, tendo

SANTOS, Renata Aparecida Felinto dos. A pálida História das Artes Visuais no Brasil: onde estamos negras e negros? 367

Revista GEARTE, Porto Alegre, v. 6, n. 2, p. 341-368, maio/ago. 2019.

Disponível em: http://seer.ufrgs.br/gearte 


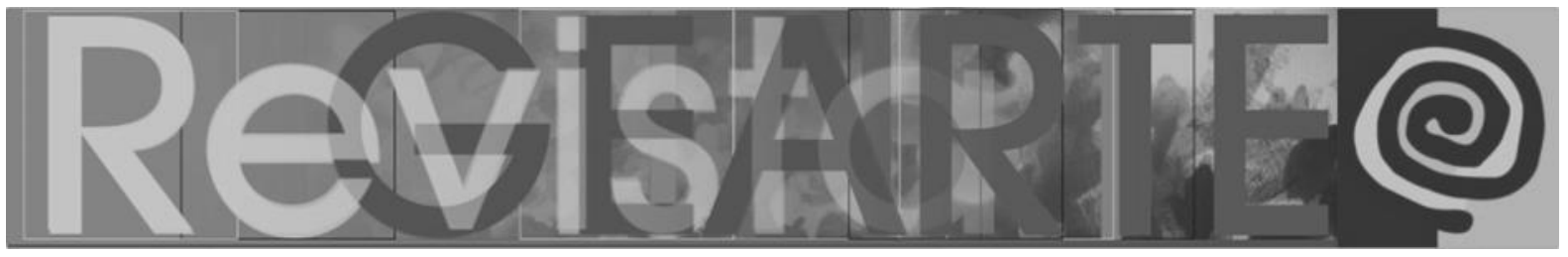

participado de diversas exposições no Brasil e no exterior apresentando desde desenhos a performances. Seus últimos trabalhos expostos foram "Diálogos Ausentes", Instituto Itaú Cultural/ SP (2016/2017); "Metrópole: Experiência Paulistana", Pinacoteca do Estado de São Paulo (2017), F Internacional de Arte Contemporânea FIAC-França (2017); Negros Indícios, na Caixa Cultural/SP (2017).

E-mail: renata.santos@urca.br

Currículo: http://lattes.cnpq.br/0927060628976765

Recebido em 20 de abril de 2019

Aceito em 21 de maio de 2019 